\title{
Continuous High-pressure Cooling-Assisted Homogenization Process for Stabilization of Apple Juice
}

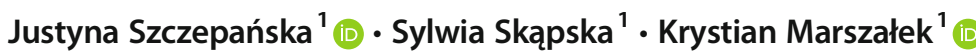

Received: 7 December 2020 / Accepted: 17 February 2021 / Published online: 24 March 2021

(C) The Author(s) 2021

\begin{abstract}
The effect of high-pressure homogenization (HPH) at 100-200 MPa (with up to 5 passes) on the quality and storage stability of apple juice was investigated. The microbiological quality, polyphenol oxidase (PPO), peroxidase (POD), polygalacturonase (PG) and pectinmethylesterase (PME) activity, particle size distribution (PSD), apparent viscosity, turbidity, concentration of vitamin $\mathrm{C}$, individual polyphenols and their total content (TPC), antioxidant activity, and colour of fresh, HPH-treated apple juice were all evaluated. The highest reduction in microorganisms $(1.4 \mathrm{log})$ and oxidoreductase activity $(\sim 20 \%)$ was observed at $200 \mathrm{MPa}$, while hydrolases did not change significantly. HPH led to significant disintegration of the tissue and a decrease in viscosity. Vitamin C decreased by $62 \%$, while TPC increased by $20 \%$ after HPH. Significant correlations were observed between antioxidant activity, TPC, and individual polyphenols. Chlorogenic, ferulic, and gallic acid were most stable at $200 \mathrm{MPa}$. The optimal shelf-life of the juice was estimated as 7 days.
\end{abstract}

Keywords Multiple passes $\cdot$ Shelf-life $\cdot$ Enzymes $\cdot$ Bioactive compounds $\cdot$ Polyphenol profile $\cdot$ Antioxidant capacity

\section{Introduction}

Apple juice is a popular drink consumed by people of all ages due to its sensory qualities. Moreover, NFC (not from concentrate) apple juices are rich in vitamins, and bioactive and mineral compounds, and exhibit good antioxidant properties (Tsao et al., 2005; Włodarska et al., 2016; Wojdyło et al., 2008; Xu et al., 2020). However, fresh fruit juices have a short shelf-life of only up to 1-2 days in refrigerated storage conditions. Therefore, it is necessary to apply a treatment that will ensure their safety for a longer period of time maintaining a high nutritional value (Saldo et al., 2009).

Justyna Szczepańska

justyna.szczepanska@ibprs.pl

Sylwia Skapska

sylwia.skapska@ibprs.pl

Krystian Marszałek

krystian.marszalek@ibprs.pl

1 Department of Fruit and Vegetable Product Technology, Prof. Wacław Dabrowski Institute of Agricultural and Food Biotechnology, 36 Rakowiecka St, 02532 Warsaw, Poland
High-pressure homogenization (HPH) is a promising non-thermal preservation technology, although intended only for liquid products, which is the major limitation of this technique. In $\mathrm{HPH}$, a pressure of $100-400 \mathrm{MPa}$ is generally used which is much higher than that used in traditional homogenization (20-50 MPa). The homogenization process carried out in devices operating under pressure above $300 \mathrm{MPa}$ is called ultra-high-pressure homogenization (Calligaris et al., 2012).

Depending on the intensity of pressure used, the product's temperature increases immediately-by $1.5-3.0^{\circ} \mathrm{C}$ for every $10 \mathrm{MPa}$ of pressure (Pereda et al., 2007; Suárez-Jacobo et al., 2012; Suárez-Jacobo et al., 2010). Therefore, it is important to use cooling systems and prevent the overheating of products.

High-pressure homogenization (HPH) is used primarily to stabilize liquid heterogeneous systems, which is achieved due to the characteristic structure of the devices, especially the homogenizing valve. The liquid substance flows through the gap in the valve of HPH devices at a very high speed. Shear forces, turbulence, and cavitation occur in the homogenizing valve gap, which cause substantial changes in the rheological and physical properties of the product, especially particle size distribution (PSD), viscosity, and turbidity. Therefore, the macromolecules, particles, and cell fragments suspended in 
the fluid are subjected to high mechanical stress, and become deformed, disrupted, and disintegrated (Augusto et al., 2012; Floury et al., 2004; Galvão et al., 2017; Dachmann et al., 2018). It is believed that the same phenomena occurring in the homogenizing valve and the high value of the pressure used contribute to the mechanical destruction of microbial cells or a violation of their structure (Augusto et al., 2018). There are a lot of literature reports confirming HPH's good potential for inactivating microorganism in fruit juices and thus for extending the shelf-life of products (Briñez et al., 2007; Donsì et al., 2009; Guan et al., 2016; Maresca et al., 2011; Pathanibul et al., 2009; Patrignani et al., 2013; A. Suárez-Jacobo et al., 2012; Á. Suárez-Jacobo et al., 2010; Velázquez-Estrada et al., 2012).

The quality of fresh fruit products, except for spoiling microorganisms, is also affected by the activity of the native enzymes contained in raw materials. Two groups of enzymes deserve special attention: oxidoreductases and hydrolases. The first group includes primarily polyphenoloxidases (PPO) and peroxidases (POD), which catalyze the oxidation of polyphenolic components, contributing to enzymatic browning and diminishing the nutritional quality. The second group includes polygalacturonases (PG and pectinmethylesterases (PME). Due to the synergistic effect of PG and PME, the degradation of pectin causes a significant change in the viscosity and consistency of products (Terefe \& Buckow, 2017; Martínez-Hernández et al., 2019).

Several studies show that good retention of colour, bioactive compounds, and antioxidant activity could be achieved in fruit juices by using HPH treatment (Donsì et al., 2009; Maresca et al., 2011; Saldo et al., 2009; Suárez-Jacobo et al., 2012), although these studies lack a comprehensive assessment of the quality of apple juice at pressures of up to $200 \mathrm{MPa}$ combined with several passes of the juice through the device. Furthermore, there are only a few papers on the application of HPH with cooling systems that allow for processing in temperatures below $35^{\circ} \mathrm{C}$. The actual temperature of the product has rarely been indicated in previous articles, and if mentioned a significant increase was observed in the temperature of the product (Bot et al., 2018; Poliseli-Scopel et al., 2012; Saldo et al., 2009).

The aim of this work was to determine the effect of HPH at different pressures and the number of passes on oxidoreductase and hydrolase activity, rheological properties, such as particle size distribution (PSD), apparent viscosity, turbidity, colour as well as the content of bioactive compounds and antioxidant potential of NFC apple juice. To carry out comprehensive research, the microbiological stability of apple juice was also evaluated to obtain information on its shelf-life during cold storage. A pressure of $150 \mathrm{MPa}$ was chosen to assess the quality of apple juice during storage, because it is the maximum pressure available in industrial devices.

\section{Materials and Methods}

\section{Preparation of Apple Juice}

A mixture of different varieties of fresh apples was purchased from a local market. The juice was obtained by pressing them in a J 80 Ultra automatic juice extractor (Robot Coupe, France) and was not clarified. The juice was stored at $4{ }^{\circ} \mathrm{C}$ for ca. $1 \mathrm{~h}$ before HPH processing. All the analyses in this study were carried out using this juice.

Due to the fact that vitamin $\mathrm{C}$ inhibits oxidoreductive enzymes (Pan et al., 2012), an additional experiment was carried out in which the apple juice was produced using a different raw material and divided into two parts, and $100 \mathrm{mg} / \mathrm{L}$ of vitamin $\mathrm{C}$ was added to one of them. Both juices were treated with $\mathrm{HPH}$ at $200 \mathrm{MPa}$. The temperature of the product did not exceed $35^{\circ} \mathrm{C}$. Juices were stored for 21 days. Additional colour parameters were measured for these juices.

\section{High-pressure Homogenization}

HPH was carried out in a laboratory-scale high-pressure homogenizer HPH 2000/4-DH5 (IKA, Germany). The experiments were carried out at different pressure levels: $100 \mathrm{MPa}$, $150 \mathrm{MPa}$, and $200 \mathrm{MPa}$; the process at $150 \mathrm{MPa}$ was also applied with 1 and up to 5 passes. Apple juice was applied using HPH with a flow rate of $1.2 \mathrm{~L} / \mathrm{h}$, and a retention time of ca. $30 \mathrm{~s}$.

The homogenizer was equipped with a cooling circulating device (Julabo F12-MA, Julabo GmbH, Germany) to control the temperature of the water flowing around the homogenization valve and counter cooling of the HPH-treated juice. A schematic diagram of the high-pressure homogenization device with a cooling circulating system is shown in Fig. 1. The temperature of the product did not exceed $35^{\circ} \mathrm{C}$ at any of the pressures used. After HPH treatment, the juices were stored in sterile glass bottles filled under aseptic conditions. Samples were assessed immediately after the HPH process to measure their rheological properties, colour parameters and microbiology. The fresh, untreated juice was used as a control sample.

\section{Storage Conditions}

Samples treated at $150 \mathrm{MPa}$ were stored at $4 \pm 1^{\circ} \mathrm{C}$, protected from light, for up to 28 days and subjected to testing at 7-day intervals.

\section{Physicochemical Analysis}

The $\mathrm{pH}$ was measured using an $\mathrm{HI} 991001 \mathrm{pH}$ meter (Hanna Instruments, USA). Density was measured using a DME 4500 density meter (Anton Paar, Austria). Total titratable acidity was assessed by titration (TitroMatic $2 \mathrm{~S}$, Crison, Spain) with 
Fig. 1 Schematic diagram of high-pressure homogenization device with cooling circulating system. 1-HP pomp, 2-intensifier, 3-feeding tank, 4- HP valve, 5 - heat exchanger counter flow, 6 - cooling system; $\mathrm{T}_{\text {in }}$ inlet temperature in the feeding tank; $\mathrm{T}_{1}, \mathrm{P}_{1}$-temperature and pressure probes located at the HPvalve inlet; $\mathrm{T}_{\text {out }}$ - out temperature

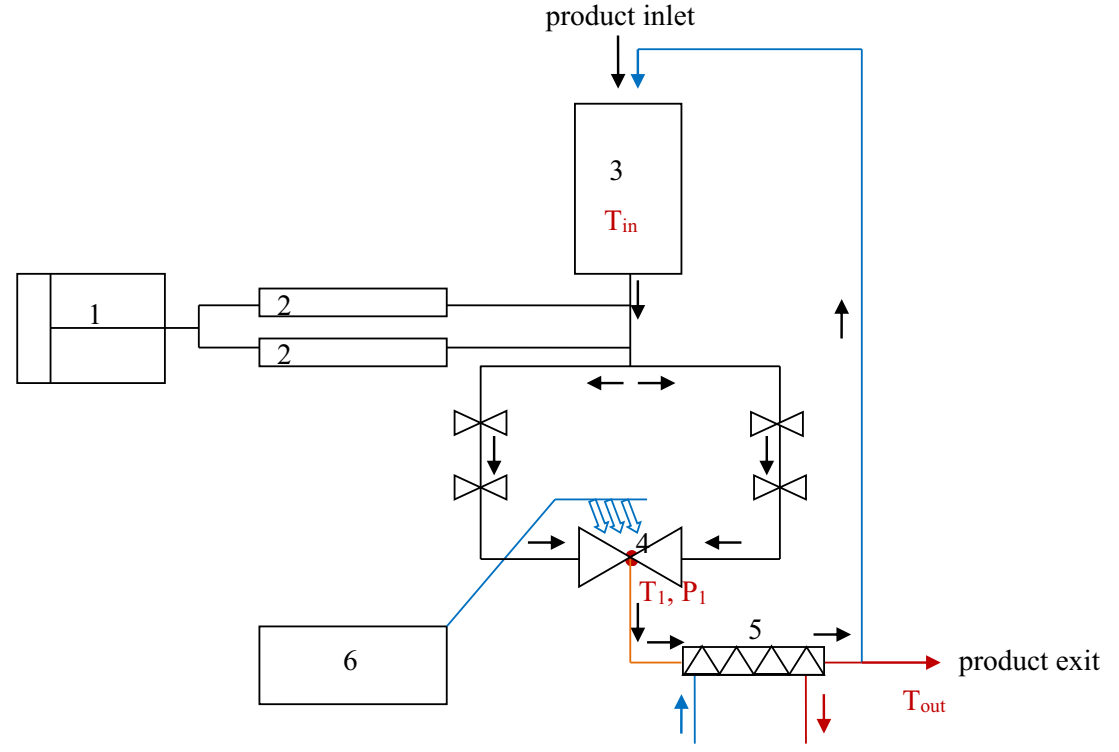

$0.1 \mathrm{~mol} / \mathrm{L} \mathrm{NaOH}$ and expressed as a percentage of malic acid. The total soluble solid (TSS) content was determined using a digital refractometer (PAL-3, Atago, USA) and expressed as Brix.

\section{HPLC Analysis of Sugars}

Glucose, fructose, and sucrose were determined according to the EN 12630:1999 standard. For the analysis, a Sugar-Pak I, $10 \mu \mathrm{m}, 6.5 \mathrm{~mm} \times 300 \mathrm{~mm}$ analytical column with a Sugar-Pak and Guard-Pak insert, $10 \mu \mathrm{m}$ (both Waters, USA), was used. The separation of the $2-\mu \mathrm{L}$ samples was performed within $20 \mathrm{~min}$ at a flow rate of $0.5 \mathrm{~mL} / \mathrm{min}$ and a column temperature of $90^{\circ} \mathrm{C}$ and a detector temperature of $35^{\circ} \mathrm{C}$. The compounds were quantified using a refractive index detector (Waters 2414, USA). Samples were eluted isocratically using $0.1 \mathrm{mM}$ calcium disodium EDTA.

\section{Microbiological Analyses}

The reduction in the total number of microorganisms, and the number of yeasts and moulds was performed according to PNEN ISO 4833-1:2013-12 and PN-ISO 21527-1:2009. Plate count agar (PCA, Merck) was used to determine total aerobic counts, incubated at $30^{\circ} \mathrm{C}$ for $72 \mathrm{~h}$. Yeasts and moulds were plated on Dichloran-Rose Bengal-Chloramphenicol Agar (DRBC, Merck) and incubated at $25^{\circ} \mathrm{C}$ for 5 to 7 days.

\section{Determination of Enzyme Activity}

\section{Determination of Polyphenoloxidase and Peroxidase Activity}

The extractions and activities of polyphenoloxidase (PPO) and peroxidase (POD) were carried out according to the methodology proposed by Terefe et al. (2010). The extraction solution consisted of a $0.2 \mathrm{M}$ sodium phosphate buffer ( $\mathrm{pH}=6.5)$ containing $1 \mathrm{M} \mathrm{NaCl}, 4 \%(\mathrm{w} / \mathrm{v})$ polyvinylpolypyrrolidone (PVPP) and 1\% (v/v) triton $\mathrm{X}-100$. The apple juice and extraction mixture $(4.5 \mathrm{~mL}: 4.5$ $\mathrm{mL}$ ) were shaken using a vortex (IKA, Germany) for $1 \mathrm{~min}$ and centrifuged (Rotina 380R, Hettich Instruments, Germany) at $11,000 \times \mathrm{g}$ for $30 \mathrm{~min}$ at $4^{\circ} \mathrm{C}$. The supernatant was centrifuged once more under the same conditions and immediately used for determination PPO and POD activity.

For the PPO assay, $300 \mu \mathrm{L}$ of the supernatant was added to $3 \mathrm{~mL}$ of $0.05 \mathrm{M}$ phosphate buffer $(\mathrm{pH}=6.5)$ containing $0.07 \mathrm{M}$ of catechol. The absorbance was measured at $\lambda=420 \mathrm{~nm}$ and $25^{\circ} \mathrm{C}$ for $10 \mathrm{~min}$ using a UV-visible spectrophotometer $(6705$ UV-vis Spectrophotometer, Jenway, UK). The blank sample was prepared using the same components, but the supernatant was replaced with a $0.05 \mathrm{M}$ phosphate buffer $(\mathrm{pH}=6.5)$.

For the POD assay, $50 \mu \mathrm{L}$ of the supernatant was added to $3 \mathrm{~mL}$ of $0.05 \mathrm{M}$ phosphate buffer $(\mathrm{pH}=6.5)$. The reaction was started by adding $50 \mu \mathrm{L}$ of $1 \%$ p-phenylenediamine $(\mathrm{w} / \mathrm{v})$ in $0.05 \mathrm{M}$ phosphate buffer ( $\mathrm{pH}=6.5$ ) and $50 \mu \mathrm{L}$ of $1.5 \%$ hydrogen peroxide $(\mathrm{v} / \mathrm{v})$. The absorbance was measured at $\lambda=485 \mathrm{~nm}$ and $25^{\circ} \mathrm{C}$ for $10 \mathrm{~min}$. A blank sample was prepared using the same components, but the supernatant was replaced with a $0.05 \mathrm{M}$ phosphate buffer $(\mathrm{pH}=6.5)$.

\section{Determination of Polygalacturonase Activity}

The activity of polygalacturonase (PG) was determined using the spectrophotometric method proposed by Pires and Finardi-Filho, (2005), with some modifications. The apple juice and $1 \mathrm{M} \mathrm{NaCl}(5 \mathrm{~mL}$ : $5 \mathrm{~mL})$ were adjusted to $\mathrm{pH}=4.0$ by adding $0.5 \mathrm{M} \mathrm{NaOH}$. The mixture was centrifuged with Rotina 380R (Hettich Instruments, Germany) at $13,000 \times g$ for 
$30 \mathrm{~min}$ at $4^{\circ} \mathrm{C}$. The supernatant was used to determine PG activity.

For the PG assay, $100 \mu \mathrm{L}$ of the supernatant was added to $90 \mu \mathrm{L}$ of $37.5 \mathrm{mM}$ Na-acetate buffer $(\mathrm{pH}=4.4)$ and $300 \mu \mathrm{L}$ of the same $\mathrm{Na}$-acetate buffer, with $0.2 \%$ of polygalacturonic acid, was incubated at $30^{\circ} \mathrm{C}$ for $2 \mathrm{~h}$. To quantify the released reducing groups, the reaction was stopped by adding $2.0 \mathrm{~mL}$ of cold $100 \mathrm{mM}$ borate buffer ( $\mathrm{pH} 9.0$ ), followed by $0.4 \mathrm{~mL}$ of $1 \%$ 2-cyanoacetamide. The samples were mixed and immersed in a boiling water bath for $10 \mathrm{~min}$. After equilibration at $25^{\circ} \mathrm{C}$, the absorbance was measured at $\lambda=276 \mathrm{~nm}$ using a UV-visible spectrophotometer (6705 UV-Vis Spectrophotometer, Jenway, UK). The blank sample was prepared using the same components, but with the enzyme extract previously boiled for $5 \mathrm{~min}$.

\section{Determination of Pectinmethylesterase Activity}

The activity of pectinmethylesterase (PME) was determined using the spectrophotometric method proposed by Hagerman and Austin, (1986), with some modifications. The apple juice was adjusted to $\mathrm{pH}=7.5$ by adding $0.1 \mathrm{M} \mathrm{NaOH}$. The mixture was centrifuged (Rotina 380R, Hettich Instruments, Germany) at $10,000 \times g$ for $10 \mathrm{~min}$ at $4^{\circ} \mathrm{C}$. The supernatant was used to determine PME activity.

For the PME assay, $0.3 \mathrm{~mL}$ of the supernatant was added to a reaction mixture composed of $2.0 \mathrm{~mL}$ of $0.5 \%(\mathrm{w} / \mathrm{v})$ citrus pectin $(\mathrm{pH}=7.5), 0.15 \mathrm{~mL}$ of $0.01 \%(\mathrm{w} / \mathrm{v})$ bromothymol blue in a $0.003 \mathrm{M}$ sodium phosphate buffer $(\mathrm{pH}=7.5)$, and $0.75 \mathrm{~mL}$ distilled water. The absorbance was measured at $\lambda=620 \mathrm{~nm}$ using a UV-visible spectrophotometer (6705 UV-vis Spectrophotometer, Jenway, UK).

\section{Calculating the Enzyme Residual Activity}

The residual activity for oxidoreductive enzymes and hydrolases was calculated according to Eq. 1:

$\mathrm{RA}(\%)=A / A_{0} \times 100$

where $A$ is the activity of the HPP-treated juice and $A_{0}$ is the activity of the fresh, untreated juice.

\section{Apparent Dynamic Viscosity}

The apparent dynamic viscosity [Pa x s] and shear stress were determined using a viscometer (Brookfield DV-II+, USA) coupled to Brookfield Wingather software, at a varying shear rate, ranging from 7.5 to $263 \mathrm{~s}^{-1}$. Shear stress values were recorded against shear rates from 7.5 to $263 \mathrm{~s}^{-1}$ during $80 \mathrm{~s}$. Possible range of shear rate was $1500 \mathrm{~s}^{-1}$. CP-40 spindle with cone $0.8^{\circ}$ was used for analysis. The measurements of a $1-\mathrm{mL}$ sample were carried out at $20^{\circ} \mathrm{C}$.

\section{Turbidity}

The turbidity of the samples was determined using a nephelometer (Hach-2100 N turbidymeter, USA). The results were expressed in NTU.

\section{Particle Size Measurements}

The particle size distribution (PSD) and mean volumetric diameters of fresh and homogenized apple juices were obtained using a Mastersizer 3000 (Malvern Instruments, Malvern, U. K.) by dispersing the samples $(25 \mathrm{~mL})$ into deionized water $(400 \mathrm{~mL})$. Laser light diffraction was used to measure particles from 0.01 to $10,000 \mu \mathrm{m}$. Parameters defining particle mean diameter, such as D[3,2], D[4,3], Dv (10), Dv (50), and Dv (90) for all samples were calculated using the software included with the equipment.

\section{Colour Parameter and Browning Index}

Colour analyses were carried out using a Color Quest XE colorimeter (HunterLab, 166 USA) equipped with a xenon flashlamp in glass cuvettes with an optical path of $1 \mathrm{~cm}$. The results were presented in accordance with the CIE L*a*b* system, using illuminant D65 and $10^{\circ}$ observer. The data was expressed as Hunter scale parameters: L* (lightness/darkness), a* (redness/greenness), and b* (yellowness/blueness) values. The total colour difference $(\Delta E)$ was calculated using equation 2 , where $L *_{0}, a^{*}{ }_{0}$ and $b^{*_{0}}$ were the values of the control sample. (Cserhalmi et al., 2006)

$$
\Delta E=\sqrt{\left(L^{*}-L^{*}{ }_{o}\right)^{2}+\left(a^{*}-a_{o}^{*}\right)^{2}+\left(b^{*}-b_{o}^{*}\right)^{2}}
$$

Depending on the value of $\Delta E$, the colour difference between the treated and untreated samples could be estimated as being unnoticeable (0-0.5), slightly noticeable (0.5-1.5), noticeable (1.5-3.0), clearly visible (3.0-6.0), and excellent (6.0-12.0) (Cserhalmi et al., 2006). Thus, the larger $\Delta E$ denotes greater colour change from the reference juice.

The browning index (BI) was calculated using Eq. 3 . (Maskan, 2001)

$\mathrm{BI}=100(x-0.31) / 0.172$

where $\mathrm{x}=\left(a^{*}+1.75 \mathrm{~L} *\right) /\left(5.645 L^{*}+a^{*-3.012 b *}\right)$ 


\section{HPLC Analysis of Vitamin C}

The total vitamin $\mathrm{C}$ content, expressed as L-ascorbic acid (AA) and L-dehydroascorbic acid (DHAA), was determined as described by Odriozola-Serrano et al. (2007). Before analysis, $1 \mathrm{~mL}$ of the sample was diluted with $1 \mathrm{~mL}$ of $0.01 \%$ phosphoric acid (determination of AA) or $1 \mathrm{~mL}$ of $1 \mathrm{~g} \mathrm{~L}^{-1}$ solution of dithiothreitol (DTT) in $0.01 \%$ phosphoric acid (determination of AA and DHAA sum). The samples with DTT were left in the cold $\left(5^{\circ} \mathrm{C}\right)$ for $1 \mathrm{~h}$ before injection. A Sunfire C18, $5 \mu \mathrm{m}, 4.6 \mathrm{~mm} \times 250 \mathrm{~mm}$ analytical column with a Sunfire C18 Sentry guard cartridge, $5 \mu \mathrm{m}, 4.6 \mathrm{~mm} \times 20 \mathrm{~mm}$ (both Waters) was used for the analysis. The compounds were quantified using a photodiode detector (Waters 2996, USA). Samples were eluted isocratically using $0.01 \% \mathrm{~m}$-phosphoric acid. The separation of the $10 \mu \mathrm{L}$ samples was performed within $10 \mathrm{~min}$ at a flow rate of $1.0 \mathrm{~mL} / \mathrm{min}$ and a column temperature of $25^{\circ} \mathrm{C}$ and sample temperature of $5^{\circ} \mathrm{C}$.

\section{Extraction Procedure for TPC, Polyphenol Profile and Antioxidant Capacity}

Five millilitres of $80 \%(\mathrm{v} / \mathrm{v})$ methanol containing $0.1 \%(\mathrm{v} / \mathrm{v})$ of $\mathrm{HCl}$ was added to $5 \mathrm{~mL}$ of apple juice. The samples were treated with ultrasound for $5 \mathrm{~min}\left(45 \mathrm{kHz}, 200 \mathrm{~W}, 25^{\circ} \mathrm{C}\right.$, MKD Ultrasonic, Poland) and centrifuged (Rotina 380R, Hettich Instruments, Germany) at $3670 \times g$ for $5 \mathrm{~min}$ at $4^{\circ} \mathrm{C}$. The supernatant was transferred to a $25-\mathrm{mL}$ flask. The extraction was repeated four times. The supernatant was filtered (pore size $0.45 \mu \mathrm{m}$, Macherey-Nagel, Germany) before analysis of TPC and antioxidant capacity with DPPH and ABTS tests.

\section{Total Content of Polyphenols}

The supernatant used to determine the TPC was prepared according to point 2.13. The phenolic compounds were determined spectrophotometrically (6705 UV-vis Spectrophotometer, Jenway, UK) using the method proposed by Gao et al. (2000). The results were expressed as milligrams of gallic acid equivalents (GAE) per $1 \mathrm{~L}$ of juice.

\section{HPLC Analysis of the Polyphenol Profile}

The supernatant used to determine individual polyphenols was prepared according to point 2.13 . The polyphenol profile was determined as described by Tsao et al. (2003). For the analysis a Sunfire C18, $5 \mu \mathrm{m}, 4.6 \mathrm{~mm} \times 250 \mathrm{~mm}$ analytical column with a Sunfire C18 Sentry guard cartridge, 5 $\mu \mathrm{m}, 4.6 \mathrm{~mm} \times 20 \mathrm{~mm}$ (both Waters) was used. The compounds were quantified using a photodiode detector (Waters 2996, USA). Samples were eluted using a gradient of $6 \%(\mathrm{v} / \mathrm{v})$ acetic acid, (solvent A) and acetonitryle-HPLC grade (solvent B), as follows: from 0 to $45 \mathrm{~min}, 100 \%$ (A); then $45-60 \mathrm{~min}, 85 \%$ (A) and $15 \%$ (B); 60-65 min, 70\% (A) and $30 \%(\mathrm{~B})$; then $65-70 \mathrm{~min}, 50 \%(\mathrm{~A})$ and $50 \%(\mathrm{~B}) ; 70-73$ min, $100 \%$ (B) and finally $73-75 \mathrm{~min}, 100 \%$ (A). The separation of the $10-\mu \mathrm{L}$ samples was performed within $75 \mathrm{~min}$ at a flow rate of $1.0 \mathrm{~mL} / \mathrm{min}$ and a column temperature of $25^{\circ} \mathrm{C}$.

\section{Antioxidant Capacity}

\section{Antioxidant Capacity Determined with DPPH}

The antioxidant capacity was measured using the $\mathrm{DPPH}^{\circ}(2,2-$ diphenyl-1-picrylhydrazyl) method as described by Yen and Chen (1995), with some modifications. The stable free radical DPPH is reduced to the corresponding hydrazine by reacting with hydrogen donors. One hundred microlitres of supernatant, prepared according to point 2.13 , was mixed with $2.0 \mathrm{~mL}$ of a $0.1 \mathrm{mM} 80 \%$ methanolic solution of DPPH. The absorbance, after $20 \mathrm{~min}$, was measured at $\lambda=520 \mathrm{~nm}$ and $25^{\circ} \mathrm{C}$ (6705 UV-vis Spectrophotometer, Jenway, UK). The results were calculated using a calibration curve prepared at different concentrations of DPPH in $80 \%$ methanol and expressed as $\mu \mathrm{M}$ Trolox equivalents (Tx).

\section{Antioxidant Capacity Determined with ABTS ${ }^{+}$}

The antioxidant capacity was measured using the $\mathrm{ABTS}^{\circ+}$ (2,2'-azino-bis(3-ethylbenzothiazoline-6-sulphonic acid)) method as described by Re et al. (1999). The $\mathrm{ABTS}^{\circ+}$ working solution was made with ABTS stock solution $(7 \mathrm{mM})$ and a potassium persulfate solution $(2.45 \mathrm{mM})$. Before the assay, the $\mathrm{ABTS}^{\circ+}$ stock solution was diluted with $80 \%$ methanol to an absorbance value of $0.740-0.750$ at $\lambda=734 \mathrm{~nm}$. Forty microlitres of supernatant, prepared according to point 2.13, was mixed with $2 \mathrm{~mL}$ of an $\mathrm{ABTS}^{*+}$ working solution. The absorbance was measured after $6 \mathrm{~h}$ of incubation at $30^{\circ} \mathrm{C}$ at $\lambda=734 \mathrm{~nm}$ and $25^{\circ} \mathrm{C}$ (6705 UV-vis Spectrophotometer, Jenway, UK). The results were calculated using a calibration curve prepared at different concentrations of $\mathrm{ABTS}^{\circ+}$ solution and expressed as $\mu \mathrm{M}$ Trolox equivalents (Tx).

\section{Statistical Analysis}

All analyses were carried out in triplicate. The results were expressed as a mean value \pm standard deviation. Statistical analysis was conducted using the STATISTICA 7.1 software (StatSoft, Tulsa, OK, USA) with a one-way analysis of the variance (ANOVA) and the Tukey test at a 95\% confidence level. 


\section{Results and Discussion}

\section{Physicochemical Characteristic}

The fresh apple juice obtained had the following basic parameters: $\mathrm{pH} 3.65$, density $1.045 \mathrm{~g} / \mathrm{cm}^{3}$, acidity $3.42 \%$ as malic acid, and total soluble solids (TSS) $10.98^{\circ}$ Brix. The total sugar content was $106.43 \mathrm{~g} / \mathrm{L}(19.58 \mathrm{~g} / \mathrm{L}$ sucrose, $18.26 \mathrm{~g} / \mathrm{L}$ glucose, $64.31 \mathrm{~g} / \mathrm{L}$ fructose, $4.29 \mathrm{~g} / \mathrm{L}$ sorbitol). All parameters were in accordance with the requirements of the Code of Practice of the Association of the Industry of Juices and Nectars (AIJN, 2015) and there were no significant differences due to HPH treatment, so this technique retains the apple juice's characteristics.

\section{Microbiological Analyses}

In fresh, untreated juice, the initial level of the microbial total count was $5.36 \log \mathrm{CFU} \mathrm{mL} \mathrm{m}^{-1}$, including the initial level of yeasts - $3.75 \log \mathrm{CFU} \mathrm{mL} \mathrm{mL}^{-1}$, and moulds-3.57 $\log \mathrm{CFU}$ $\mathrm{mL}^{-1}$ (Fig. 2 A). The use of HPH caused a decrease in the total count of $0.6-1.4 \log \mathrm{CFU} \mathrm{mL} \mathrm{m}^{-1}$. The reduction in yeasts and moulds ranged from $0.2-0.61 \log \mathrm{CFU} \mathrm{mL} \mathrm{m}^{-1}$ to $0.3-0.6$ $\log \mathrm{CFU} \mathrm{mL} \mathrm{m}^{-1}$, respectively, depending on the pressure applied. These results are in accordance with the results published by McKay et al. (2011), who obtained about $0.6 \mathrm{log}$ $\mathrm{CFU} \mathrm{mL}{ }^{-1}$ reduction for yeast, moulds, and the total aerobic count in apple juice treated with HPH at $150 \mathrm{MPa}$.

In this study, multiple passes were used, because some reports noted that the use of several passes increased the level of reduction of microorganisms (Guan et al., 2016; Maresca et al., 2011; Patrignani et al., 2010). Taking account of the fact that industrial devices can work at pressures of up to $150 \mathrm{MPa}$, the use of several passes seemed to be a reasonable solution in terms of improving the microbiological quality of the juice. However, the use of additional passes did not significantly affect the total microbial count, moulds, or yeasts (data not shown).

After 7 days of storage at $4^{\circ} \mathrm{C}$ (Fig. 2 B), an increase of 1.2 $\log \mathrm{CFU} \mathrm{mL} \mathrm{m}^{-1}$ in the number of yeasts was observed in the sample subjected to pressure at $150 \mathrm{MPa}$, whereas the total aerobic count and number of moulds did not change significantly. The number of moulds remained stable until the end of the storage time which indicates that those microorganisms
Fig. 2 Influence of (A) HPH pressure level, (B) storage at $4{ }^{\circ} \mathrm{C}$ on total microbial count (TMC), molds, and yeasts in fresh and HPH-treated apple juice
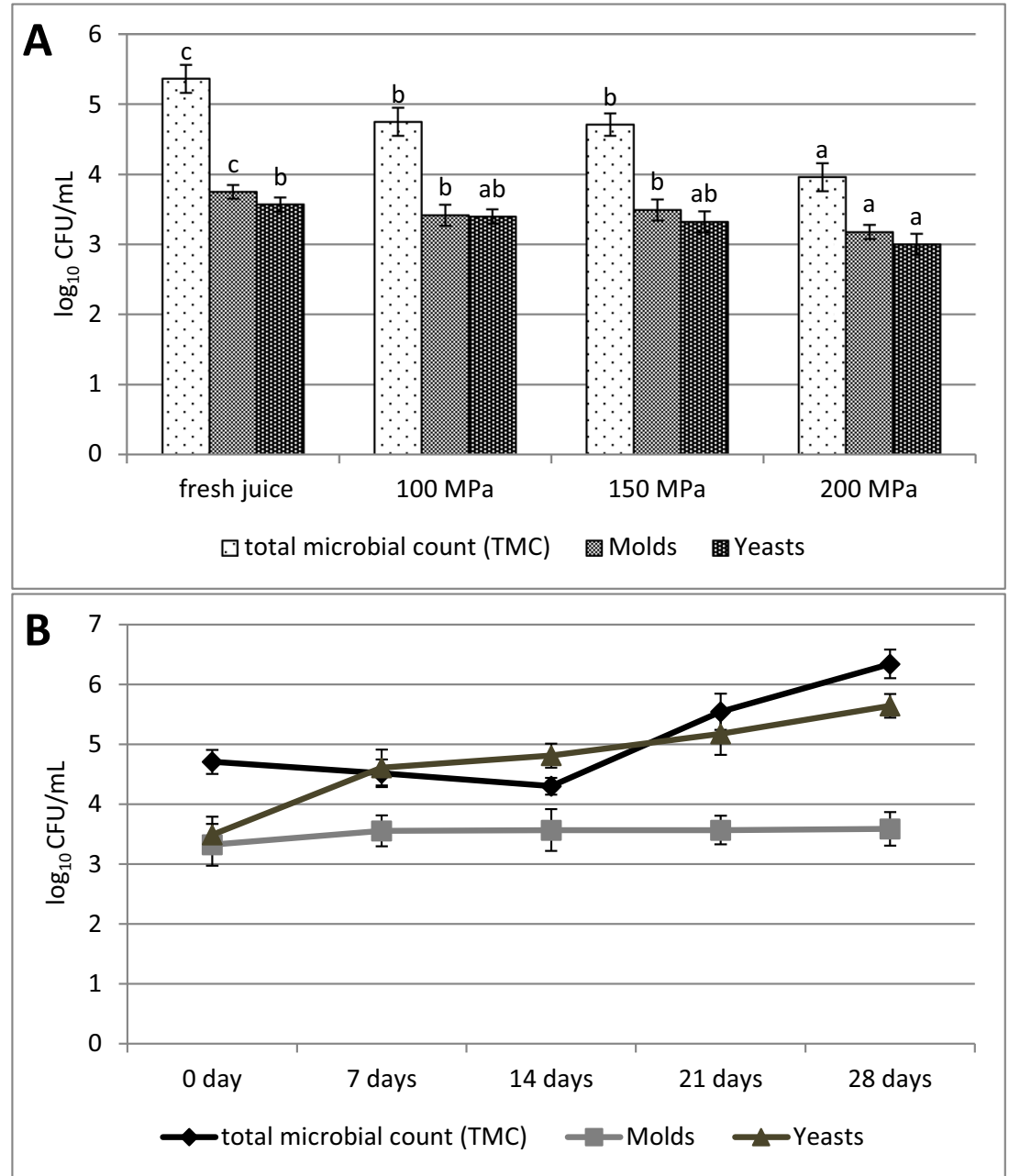
were not able to grow at $4^{\circ} \mathrm{C}$ in apple juice. Twenty-one days after homogenization, the total number of microorganisms increased, exceeding the initial level determined in fresh apple juice.

The reduction of microorganisms using HPH depends on several factors, e.g. pressure and temperature. According to Carreño et al. (2011), and Vachon et al. (2002), increased temperature weakens the hydrogen and hydrophobic bonds, which results in lower cell membrane resistance to HPH. Moreover, the forces in the homogenizing valve may contribute to the disruption of the microbial cells. Studies carried out by Guan et al. (2016) indicate that microbial reduction in mango juice homogenized at $190 \mathrm{MPa}, 20^{\circ} \mathrm{C}$ was $0.54 \log \mathrm{CFU} \mathrm{mL} \mathrm{m}^{-1}$, but increasing the temperature to $60^{\circ} \mathrm{C}$ resulted in a greater reduction, of $2.32 \log \mathrm{CFU} \mathrm{mL} \mathrm{m}^{-1}$.

\section{Polyphenol Oxidase and Peroxidase Activity}

Figure 3 A shows the residual activity of PPO and POD in fresh and $\mathrm{HPH}$-treated apple juices. Applying the highest pressure $(200 \mathrm{MPa})$ resulted in a decrease in the PPO and POD activity of $21.5 \%$ and $16.4 \%$ respectively compared to fresh juice. This phenomenon may be caused by the strong mechanical damage to the cells in the juice, which in turn could lead to the release of enzymes encapsulated in plant vacuoles, making them susceptible to inactivation. CodinaTorrella et al. (2017) noted a similar reduction of POD activity $(\sim 20 \%)$ at the same pressure level in tiger nut milk.

The application of multi-pass HPH did not influence the level of oxidoreductive enzymes (Fig. 3 B); the changes observed were not statistically significant. In addition, during 28 days of storage, no significant changes in PPO and POD activity were observed, which indicate that especially POD was not able to regenerate (Fig. 3 C).

\section{Polygalacturonases Activity}

The residual activity of polygalacturonase (PG) after HPH treatment is shown in Fig. $3 \mathrm{~A}$. The use of HPH resulted in a slight, but insignificant increase of PG activity; also, the use of multiple passes did not statistically affect the activity of this enzyme (Fig. 3 B). In turn, significant changes in PG activity occurred during storage (Fig. 3 C). On the 14th day of storage, PG activity decreased by $38.5 \%$ and remained at a similar level until the end of the storage. PG may affect the rheological properties of products, especially viscosity (Eisenmenger \& Reyes-De-Corcuera, 2009). In this study, the correlation coefficient between PG activity and apparent viscosity was 0.729 (significant at $p \leq 0.05$ ), indicating the effect of residual PG activity on juice viscosity during storage.
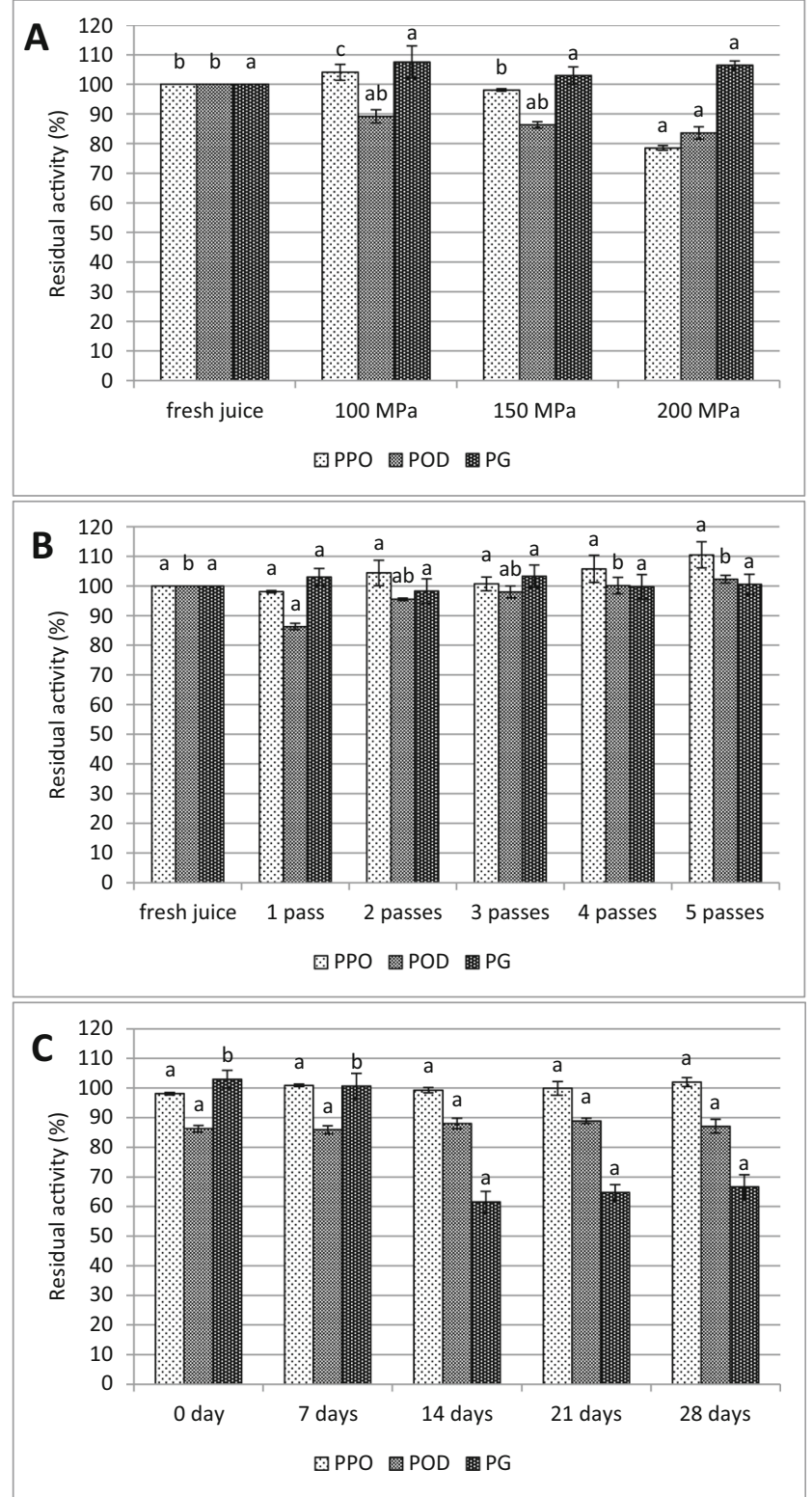

Fig. 3 Influence of(A) HPH pressure level, (B) number of HPH passes at $150 \mathrm{MPa}$, and $(\mathrm{C})$ storage at $4{ }^{\circ} \mathrm{C}$ on residual activity of polyphenoloxidases (PPO), peroxidases (POD), and polygalacturonases $(\mathrm{PG})$ in fresh and $\mathrm{HPH}$-treated apple juice

\section{Pectinmethylesterases Activity}

In this study, PME activity was not detectable in fresh apple juice, after processing and during storage. There are several studies about the influence of HPH treatment on PME activity in citrus juices (Carbonell et al., 2013; Carreño et al., 2011; Cerdán-Calero et al., 2013; Lacroix et al., 2005; Navarro et al., 2014; Velázquez-Estrada et al., 2012; Welti-Chanes et al., 2009). PME activity in apple juice after HPH has only been studied by A. Suárez-Jacobo et al. (2012), who noted that there was no activity after treatment and during storage for 60 days. It should be mentioned that PME is added when 
processing commercial apple juice to facilitate extraction and filtration in order to produce clear apple juice. The added PME is usually heat-inactivated after juice extraction; otherwise, the cloud formed by the pectin is destabilized by the activity of this enzyme (Riahi \& Ramaswamy, 2003).

\section{Apparent Dynamic Viscosity}

The rheological properties of HPH-treated samples are connected with the structural changes due to high turbulence, cavitation, impact, and shear forces, such as the destruction of the internal structure during the flow of the product through the homogenizing valve. Figure $4 \mathrm{~A}$ and $\mathrm{B}$ show the dependence between apparent viscosity and the shear rate (at a range of from 7.5 to $\left.263.0 \mathrm{~s}^{-1}\right)$. The apparent dynamic viscosity decreased in line with the increased shear rate, which could be because the molecules becoming less dependent on each other and consequently presenting less resistance to flow under an increase in the shear rate (Steffe et al., 1983). The fresh apple juice showed a higher apparent viscosity independent of the shear rate. The trend observed shows a significant decrease in the apparent viscosity of the apple juice when processed using HPH. The minimum viscosity was observed at $200 \mathrm{MPa}$ which may be connected with the more significant changes in particle size distribution. During HPH treatment, particle aggregates are broken up and smaller particles are formed which may directly affect the viscosity. Similar results were demonstrated by Leite et al. (2014) in their research on concentrated orange juice. The authors concluded that as pressure increases, the apparent viscosity decreases. Contradictory results were obtained by Zhou et al. (2017). The authors suggested that the increase in apparent viscosity after applying HPH could be caused partly by the increase in solubility of high-molecular carbohydrates such as starch and pectin. The inactivation of pectin-degrading enzymes by HPH prevents pectin depolymerization, which results in a higher serum viscosity and higher juice consistency.

The apparent viscosity did not change significantly when several passes were used; therefore, the results were not presented. Contradictory results were obtained by Patrignani et al. (2010). The viscosity of carrot juice decreased, whereas apricot juices increased after treatment using HPH at $100 \mathrm{MPa}$. The results obtained were attributed to the modification of proteins, polysaccharides, and pectin. Moreover, the authors assumed that HPH treatment enhances the activity of pectinmethylesterase (PME). But in this study, PME activity was not detectable in fresh apple juice, after processing and during storage.

The apparent viscosity increased during storage, especially on the 14th day and later. The residual activity of PG may affect the apparent viscosity, as evidenced by a correlation coefficient ( $r=0.729$, significant at $p \leq 0.05$ ).
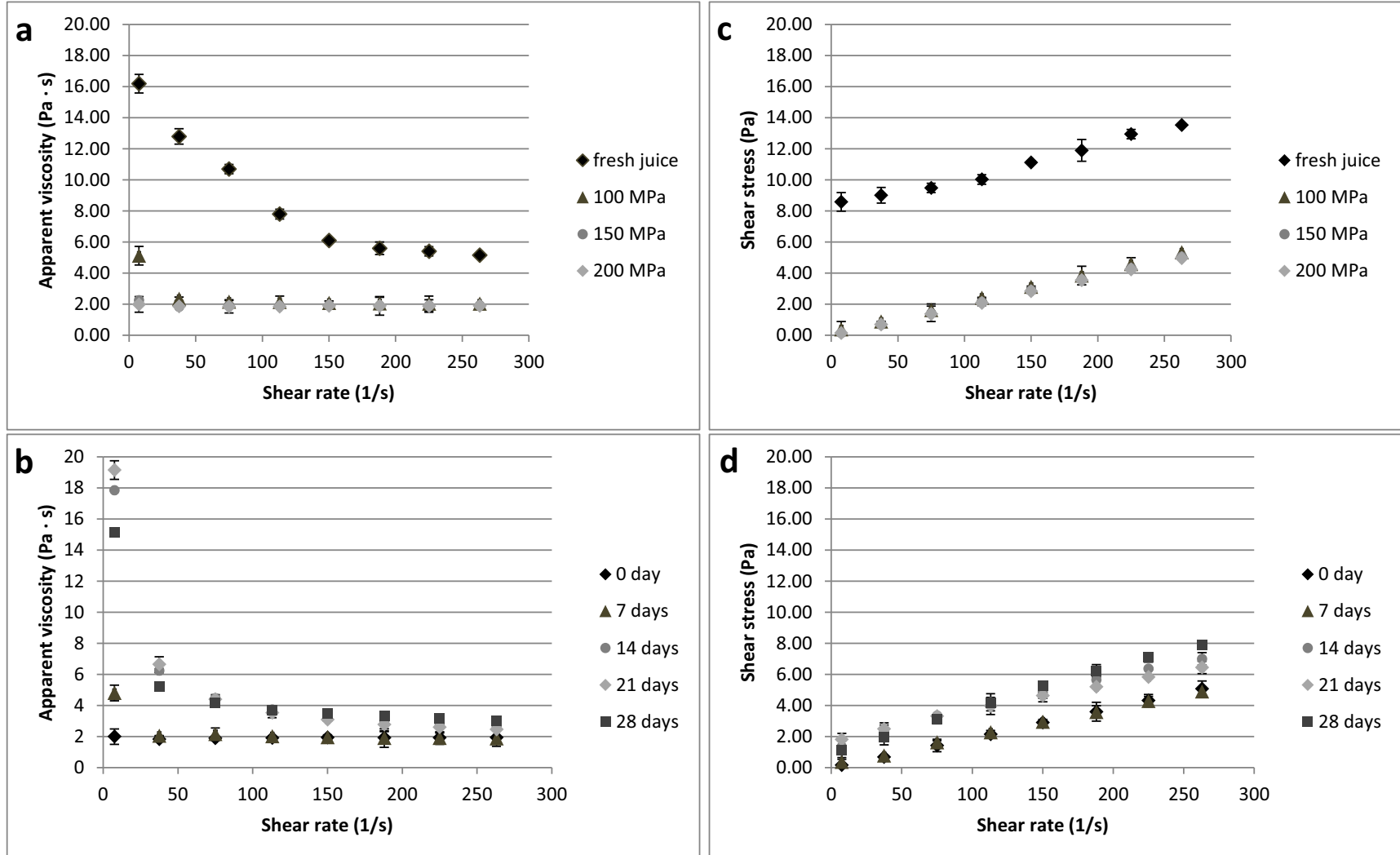

Fig. 4 Effect of (A) HPH pressure level and (B) storage at $4{ }^{\circ} \mathrm{C}$ on apparent dynamic viscosity and (C) $\mathrm{HPH}$ pressure level and (D) storage at $4{ }^{\circ} \mathrm{C}$ on the shear stress of apple juice 
Figure $4 \mathrm{C}$ and D show shear stress versus shear rate (range from 7.5 to $263.0 \mathrm{~s}^{-1}$ ) for fresh apple juice and processed using HPH. The shear stress has changed after homogenization and during measurement. The change in the particle size distribution (PSD) caused by the breakdown of suspended particles into smaller particles resulted in the reduction in shear stress, because smaller particles are less resistant to shear and show less friction during flow. Moreover, when the shear rate changes during measurement, the product structure also changes, i.e. the internal structure is destroyed during flow, which also causes a decrease in the apparent viscosity or shear stress (Leite et al., 2014; Rao et al., 2014; Leite et al., 2016).

The changes during the serum phase have a significant influence on the product's rheology, which was also emphasized by Leite et al. (2014). They used HPH treatment to reduce the consistency of concentrated orange juice, and they noticed a decrease in shear stress as the pressure used increased. Tan and Kerr (2015) studied the changes in the rheological properties under high-pressure homogenization and they noticed far bigger differences between fresh and HPH-treated tomato puree samples than in this study. This may be due to the different microstructural features, such as the amount of tissue embedded in the aqueous layer of the products, different PSD and pressures used in homogenization.

The number of passes did not significantly affect the shear stress (the results are not presented), whereas changes during storage were observed (Fig. 4 D). Storage at $4^{\circ} \mathrm{C}$ for 7 days did not have a significant impact on shear stress, but longer storage of samples resulted in an increase in the values analyzed.

\section{Turbidity}

High-pressure homogenization significantly affected the turbidity of apple juice. As the pressure applied increased, the juices become less turbid (Table 1), which is related directly to the particle size distribution (Fig. 5). Larger juice particles are broken down by homogenization and the smaller particles fill the gaps among the bigger ones, so the juice becomes less turbid. Therefore, the fruit tissue cells and their fragments are dispersed in an aqueous solution of soluble polysaccharides, sugars, and acids. The particles suspended in the aqueous solution are directly responsible for the absorption of radiation (Augusto et al., 2012). Similar results for this study were obtained by Kubo et al. (2013) in tomato juice under $\mathrm{HPH}$ treatment.

After applying the third pass, the turbidity decreased, but subsequent passes did not have a significant effect on the turbidity values (Table 1). Table 1 also shows the turbidity changes during 28 days of storage. The juice immediately after HPH treatment at $150 \mathrm{MPa}$ and juices stored for 14 days constituted the same homogeneous group according to the turbidity value. From the 21 st day of storage, the juices became more turbid. This may be due to the growth of microorganisms (Fig. 2). In the studies of Kubo et al. (2013), the

Table 1 Effect of $\mathrm{HPH}$ pressure level, number of $\mathrm{HPH}$ passes, and storage at $4{ }^{\circ} \mathrm{C}$ on the turbidity, colour parameters, and vitamin $\mathrm{C}$ content of apple juice

\begin{tabular}{lcllllll}
\hline & Turbidity (NTU) & $L^{*}$ & $a^{*}$ & $b^{*}$ & $\Delta E$ & BI & Vitamin C (mg/L) \\
\hline Influence of HPH pressure & & & & & & & \\
Fresh juice & $1438.3 \pm 10.1 \mathrm{c}$ & $72.16 \pm 0.02 \mathrm{~d}$ & $4.36 \pm 0.01 \mathrm{~b}$ & $38.86 \pm 0.02 \mathrm{~d}$ & - & $77.55 \pm 0.07 \mathrm{a}$ & $128.57 \pm 2.16 \mathrm{c}$ \\
$100 \mathrm{MPa}$ & $1315.0 \pm 4.1 \mathrm{~b}$ & $68.89 \pm 0.01 \mathrm{c}$ & $4.09 \pm 0.01 \mathrm{a}$ & $38.27 \pm 0.02 \mathrm{~b}$ & $3.33 \pm 0.01 \mathrm{a}$ & $80.72 \pm 0.03 \mathrm{~b}$ & $82.07 \pm 1.22 \mathrm{~b}$ \\
$150 \mathrm{MPa}$ & $1277.3 \pm 5.6 \mathrm{a}$ & $68.02 \pm 0.01 \mathrm{~b}$ & $4.08 \pm 0.01 \mathrm{a}$ & $38.70 \pm 0.02 \mathrm{c}$ & $4.15 \pm 0.00 \mathrm{~b}$ & $83.42 \pm 0.06 \mathrm{c}$ & $59.45 \pm 1.05 \mathrm{a}$ \\
$200 \mathrm{MPa}$ & $1272.8 \pm 5.9 \mathrm{a}$ & $65.17 \pm 0.01 \mathrm{a}$ & $4.41 \pm 0.01 \mathrm{c}$ & $38.02 \pm 0.02 \mathrm{a}$ & $7.04 \pm 0.01 \mathrm{c}$ & $86.94 \pm 0.08 \mathrm{~d}$ & $49.08 \pm 4.43 \mathrm{a}$ \\
Influence of passes & & & & & & \\
$150 \mathrm{MPa} / 1$ pass & $1277.3 \pm 5.6 \mathrm{~b}$ & $68.02 \pm 0.01 \mathrm{~d}$ & $4.08 \pm 0.01 \mathrm{~d}$ & $38.70 \pm 0.02 \mathrm{~d}$ & $4.15 \pm 0.00 \mathrm{a}$ & $83.42 \pm 0.06 \mathrm{~d}$ & $59.45 \pm 1.05 \mathrm{a}$ \\
$150 \mathrm{MPa} / 2$ passes & $1262.5 \pm 5.4 \mathrm{~b}$ & $67.36 \pm 0.01 \mathrm{c}$ & $3.59 \pm 0.01 \mathrm{c}$ & $38.01 \pm 0.02 \mathrm{c}$ & $4.93 \pm 0.01 \mathrm{~b}$ & $81.96 \pm 0.04 \mathrm{c}$ & $60.98 \pm 1.03 \mathrm{a}$ \\
$150 \mathrm{MPa} / 3$ passes & $1229.5 \pm 7.5 \mathrm{a}$ & $67.08 \pm 0.01 \mathrm{~b}$ & $3.61 \pm 0.01 \mathrm{c}$ & $37.68 \pm 0.03 \mathrm{~b}$ & $5.27 \pm 0.01 \mathrm{c}$ & $81.50 \pm 0.01 \mathrm{~b}$ & $60.22 \pm 1.27 \mathrm{a}$ \\
$150 \mathrm{MPa} / 4$ passes & $1237.5 \pm 10.1 \mathrm{a}$ & $66.80 \pm 0.01 \mathrm{a}$ & $3.50 \pm 0.02 \mathrm{~b}$ & $37.60 \pm 0.02 \mathrm{a}$ & $5.57 \pm 0.01 \mathrm{~d}$ & $81.61 \pm 0.07 \mathrm{~b}$ & $57.81 \pm 1.07 \mathrm{a}$ \\
$150 \mathrm{MPa} / 5$ passes & $1235.8 \pm 7.4 \mathrm{a}$ & $66.78 \pm 0.01 \mathrm{a}$ & $3.30 \pm 0.01 \mathrm{a}$ & $37.57 \pm 0.01 \mathrm{a}$ & $5.63 \pm 0.01 \mathrm{e}$ & $81.32 \pm 0.01 \mathrm{a}$ & $56.66 \pm 1.37 \mathrm{a}$ \\
Influence of storage time & & & & & \\
$150 \mathrm{MPa} / 0$ day & $1277.3 \pm 5.6 \mathrm{a}$ & $68.02 \pm 0.01 \mathrm{~d}$ & $4.08 \pm 0.01 \mathrm{~b}$ & $38.70 \pm 0.02 \mathrm{~b}$ & $4.15 \pm 0.00 \mathrm{a}$ & $83.42 \pm 0.06 \mathrm{a}$ & $59.45 \pm 1.05 \mathrm{~d}$ \\
$150 \mathrm{MPa} / 7$ days & $1269.8 \pm 7.0 \mathrm{a}$ & $67.90 \pm 0.03 \mathrm{~d}$ & $3.81 \pm 0.02 \mathrm{a}$ & $38.27 \pm 0.02 \mathrm{a}$ & $4.33 \pm 0.02 \mathrm{~b}$ & $82.06 \pm 0.13 \mathrm{a}$ & $39.18 \pm 0.59 \mathrm{c}$ \\
$150 \mathrm{MPa} / 14$ days & $1265.0 \pm 10.2 \mathrm{a}$ & $57.29 \pm 0.11 \mathrm{c}$ & $9.21 \pm 0.10 \mathrm{c}$ & $54.47 \pm 0.10 \mathrm{c}$ & $22.10 \pm 0.07 \mathrm{c}$ & $197.41 \pm 0.59 \mathrm{~b}$ & $9.07 \pm 0.22 \mathrm{~b}$ \\
$150 \mathrm{MPa} / 21$ days & $2005.5 \pm 7.7 \mathrm{~b}$ & $54.70 \pm 0.14 \mathrm{~b}$ & $14.73 \pm 0.02 \mathrm{~d}$ & $63.14 \pm 0.12 \mathrm{~d}$ & $31.65 \pm 0.03 \mathrm{~d}$ & $301.44 \pm 0.45 \mathrm{c}$ & $7.92 \pm 0.17 \mathrm{~b}$ \\
$150 \mathrm{MPa} / 28$ days & $2557.5 \pm 22.7 \mathrm{c}$ & $48.89 \pm 0.07 \mathrm{a}$ & $18.76 \pm 0.17 \mathrm{e}$ & $65.26 \pm 0.07 \mathrm{e}$ & $38.02 \pm 0.03 \mathrm{e}$ & $437.45 \pm 1.83 \mathrm{~d}$ & $5.25 \pm 0.07 \mathrm{a}$ \\
\hline
\end{tabular}

Data are presented as the mean \pm S.D. from three independent experiments. Different letters in the same columns means statistically significant differences $(p>0.05)$ 

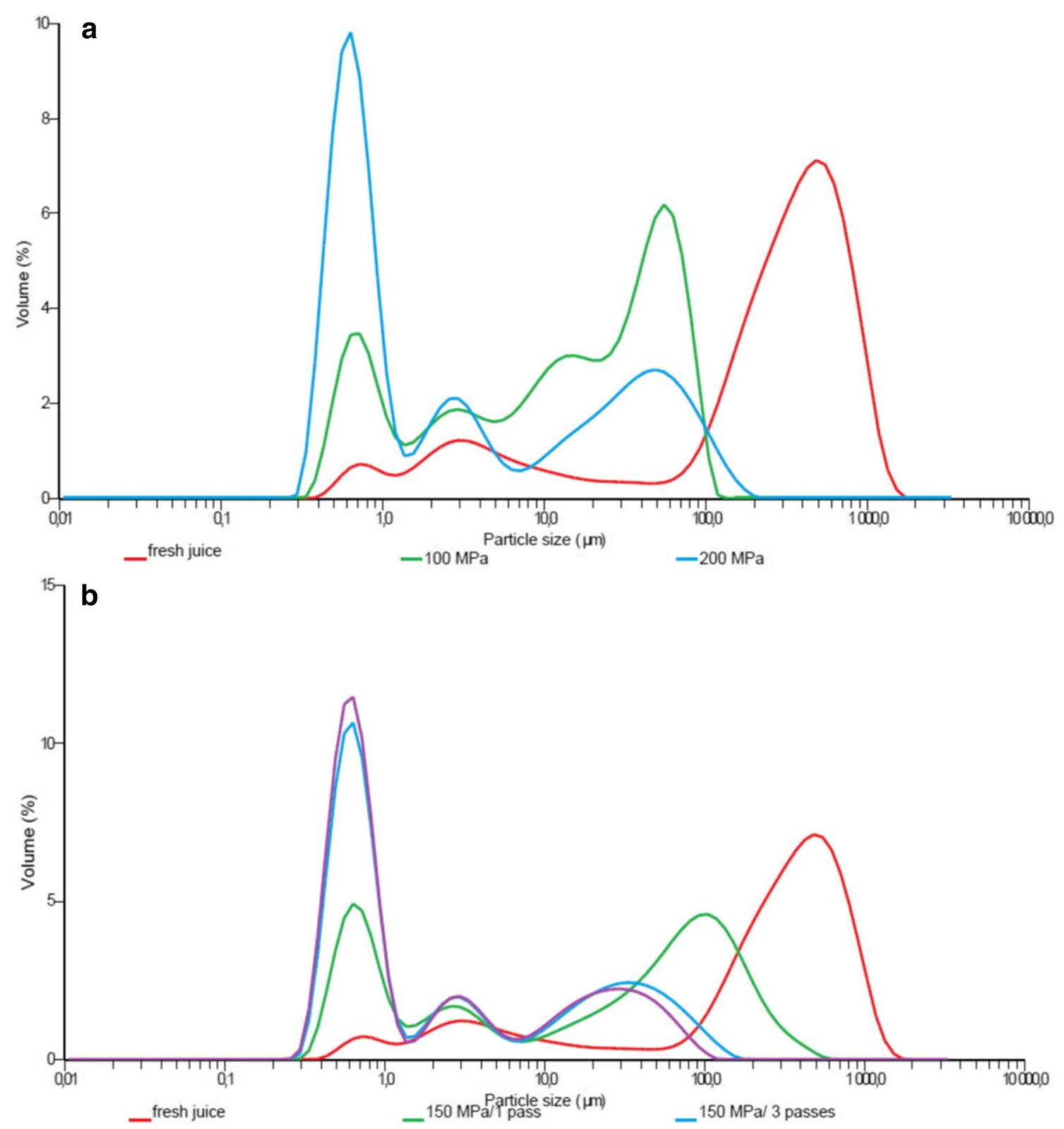

_ $150 \mathrm{MPa} / 5$ passes

Fig. 5 Influence of (A) HPH pressure level and (B) number of HPH passes on the particle size distribution (PSD) of apple juice

turbidity of tomato juice treated at $100 \mathrm{MPa}$ was maintained at a similar level during 60 days of storage, but potassium sorbate was added to preserve the microbial stability during the whole period of the storage experiment at $25^{\circ} \mathrm{C}$. Furthermore, Carbonell et al. (2013) found that the cloudiness of orange juice was stable for 90 days of storage at $3^{\circ} \mathrm{C}$, despite the increase in the residual activity of PME (up to $25 \%$ ).

\section{Particle Size Distribution}

An important parameter of the juice stability assessment is the particle size of the suspension. The reduction in particle size makes the juices more stable for sedimentation, since phase separation is avoided. Homogenization has a very strong effect on the PSD. The effect of HPH on particle size distribution and the mean particle diameter of apple juice are shown in Fig. 5 and Table 2, respectively. The untreated apple juice showed a monomodal distribution, with particle diameters ranging between ca. 0.5 and $1200 \mu \mathrm{m}$. Homogenization at $100 \mathrm{MPa}$ had a very strong effect on PSD, because the main peak moved towards smaller particle diameters. The average particle size (the Dv (50) value) of $308 \mu \mathrm{m}$ decreased to $15.8 \mu \mathrm{m}$ and the mean particle diameters D [3,2] and D $[4,3]$ were reduced by $73.4 \%$ and $92.7 \%$, respectively. This indicates a considerable increase in the number of smaller particles with a diameter of up to $100 \mu \mathrm{m}$. As the pressure 
Table 2 Effect of HPH pressure level and number of HPH passes on the mean particle diameter of apple juice

\begin{tabular}{|c|c|c|c|c|c|}
\hline & $\mathrm{D}[3,2]$ & $\mathrm{D}[4,3]$ & Dv (10) & Dv (50) & Dv (90) \\
\hline \multicolumn{6}{|c|}{ Influence of HPH pressure } \\
\hline Fresh juice & $10.50 \pm 0.10 \mathrm{~d}$ & $359.10 \pm 0.57 \mathrm{~d}$ & $3.50 \pm 0.06 \mathrm{~d}$ & $308.00 \pm 1.26 \mathrm{~d}$ & $781.50 \pm 1.30 \mathrm{~d}$ \\
\hline $100 \mathrm{MPa}$ & $2.79 \pm 0.04 \mathrm{c}$ & $26.31 \pm 0.16 b$ & $0.73 \pm 0.02 \mathrm{c}$ & $15.80 \pm 0.12 b$ & $67.17 \pm 0.20 \mathrm{~b}$ \\
\hline $150 \mathrm{MPa}$ & $2.12 \pm 0.02 b$ & $61.22 \pm 0.21 \mathrm{c}$ & $0.60 \pm 0.03 b$ & $30.10 \pm 0.16 \mathrm{c}$ & $165.04 \pm 0.25 \mathrm{c}$ \\
\hline $200 \mathrm{MPa}$ & $1.10 \pm 0.01 \mathrm{a}$ & $17.10 \pm 0.09 \mathrm{a}$ & $0.48 \pm 0.01 \mathrm{a}$ & $1.19 \pm 0.05 \mathrm{a}$ & $59.60 \pm 0.18 \mathrm{a}$ \\
\hline \multicolumn{6}{|l|}{ Influence of passes } \\
\hline $150 \mathrm{MPa} / 1$ pass & $2.12 \pm 0.02 \mathrm{c}$ & $61.22 \pm 0.21 \mathrm{e}$ & $0.60 \pm 0.03 \mathrm{a}$ & $30.10 \pm 0.16 \mathrm{c}$ & $165.04 \pm 0.25 \mathrm{e}$ \\
\hline $150 \mathrm{MPa} / 2$ passes & $1.23 \pm 0.06 \mathrm{~b}$ & $19.60 \pm 0.05 \mathrm{~d}$ & $0.49 \pm 0.11 \mathrm{a}$ & $2.25 \pm 0.08 \mathrm{~b}$ & $64.89 \pm 0.30 \mathrm{~d}$ \\
\hline $150 \mathrm{MPa} / 3$ passes & $1.01 \pm 0.03 \mathrm{a}$ & $13.15 \pm 0.04 \mathrm{c}$ & $0.47 \pm 0.08 \mathrm{a}$ & $0.93 \pm 0.06 \mathrm{a}$ & $45.40 \pm 0.39 \mathrm{c}$ \\
\hline $150 \mathrm{MPa} / 4$ passes & $0.93 \pm 0.01 \mathrm{a}$ & $11.35 \pm 0.05 b$ & $0.46 \pm 0.07 \mathrm{a}$ & $0.83 \pm 0.04 \mathrm{a}$ & $37.77 \pm 0.15 b$ \\
\hline $150 \mathrm{MPa} / 5$ passes & $0.93 \pm 0.02 \mathrm{a}$ & $9.40 \pm 0.02 \mathrm{a}$ & $0.46 \pm 0.04 \mathrm{a}$ & $0.83 \pm 0.03 \mathrm{a}$ & $33.83 \pm 0.08 \mathrm{a}$ \\
\hline
\end{tabular}

Data are presented as the mean \pm S.D. from three independent experiments. Different letters in the same columns means statistically significant differences $(p>0.05)$ increases, the peak centred around 0.5 to $1.0 \mu \mathrm{m}$ which implies that the larger particles were disintegrated into smaller ones. Therefore, particle distribution became more uniform at a higher pressure. A similar behaviour was observed in earlier studies carried out on fruit juices (Augusto et al., 2013; Donsì et al., 2009; Karacam et al., 2015; Kubo et al., 2013; Leite et al., 2014; Zhou et al., 2017).

The mean particle size decreased as the number of passes increased. The second pass at $150 \mathrm{MPa}$ was able to disrupt the residual larger particles. The mean particle diameters $\mathrm{D}[3,2]$ and $\mathrm{D}[4,3]$ were reduced by $42.0 \%$ and $68.0 \%$ compared to the first pass and by $88.3 \%$ and $94.5 \%$ compared to the control sample. However, additional passes did not lead to a noticeable reduction in particle size (Fig. 5 B). Very similar results were obtained by Donsì et al. (2009) with apple juice. The authors noticed that HPH at $200 \mathrm{MPa}$ with subsequent (more than two) passes did not change the distribution of the particles in the juice; moreover, two passes at $200 \mathrm{MPa}$ had a similar effect on particle size distribution as the use of a higher pressure of $300 \mathrm{MPa}$. On the other hand, in the study conducted by Zhou et al. (2017), it was concluded that subsequent passes reduced the average particle size, although only a small reduction occurred between the third and fifth pass.

\section{Colour Parameters}

Table 1 shows the colour parameters of fresh apple juice, and juices after $\mathrm{HPH}$ treatment and during storage for 28 days at $4^{\circ} \mathrm{C}$. High-pressure homogenization caused a significant darkening of all the preserved samples compared to the fresh juice $(p<0.05)$. The $L^{*}$ values decreased as the pressure and pass number increased. After the HPH process, values $a^{*}$ and $b^{*}$ also changed, and the juices became less yellow and red. The total colour difference $(\Delta E)$ in juice preserved at $100 \mathrm{MPa}$ indicates that the colour changes were noticeable but visible only to an experienced observer, whereas at higher pressure (150 MPa, $200 \mathrm{MPa}$ ) and after several passes, the $\Delta E$ parameter was higher which suggests that changes in the colour would also be visible to an inexperienced observer. Zhou et al. (2017) reported that the $\Delta E$ parameter of apple juice after HPH treatment increased with the increase in the number of passes from 1 to 5 . The increasing $\Delta E$ value can be explained by more oxygen dissolved in the juice during HPH treatment with several passes which favours the browning reactions. Additionally, increasing the number of passes prolongs the treatment time.

The browning degree (BI) coefficient represents the purity of the brown colour. The higher the pressure applied, the higher the $\mathrm{BI}$ value observed. However, the greatest changes in this parameter were recorded in stored juices, especially on the 14th day of storage and later. This is similar to the results of Donsì et al. (2009) with apple juice stored at $37^{\circ} \mathrm{C}$. The authors explained the colour deviation as a result of enzymatic activity. Color changes can also be caused by non-enzymatic browning reactions.

Due to the fact that significant colour changes were observed, an experiment with the addition of vitamin $\mathrm{C}$ to the apple juice treated with HPH was performed. Table 3 presents the colour parameters of juices from another raw material with the addition of $100 \mathrm{mg} / \mathrm{L}$ vitamin $\mathrm{C}$ as an inhibitory agent against oxidoreductive enzymes. After the HPH process, the $L^{*}$ and $a^{*}$ values decreased, whereas the parameter $b^{*}$ increased. In samples with the addition of vitamin $\mathrm{C}$, the $\Delta E$ parameter was lower, which indicates a smaller difference in the colour between this sample and the control sample than in the case of samples without vitamin C. Furthermore, the addition of vitamin $\mathrm{C}$ caused a lower value of the browning degree coefficient.

\section{Content of Vitamin C}

L-ascorbic acid (AA) was not found in any sample. The initial content of L-dehydroascorbic acid (DHAA), an oxidized form 
Table 3 Influence of vitamin $\mathrm{C}$ addition $(100 \mathrm{mg} / \mathrm{L})$ and storage at $4{ }^{\circ} \mathrm{C}$ on the colour parameters of apple juice treated at $200 \mathrm{MPa}$

\begin{tabular}{llllll}
\hline & $L^{*}$ & $a^{*}$ & $b^{*}$ & $\Delta E$ & BI \\
\hline Fresh juice & $76.16 \pm 0.04 \mathrm{c}$ & $2.08 \pm 0.03 \mathrm{c}$ & $31.19 \pm 0.03 \mathrm{a}$ & - & $52.57 \pm 0.12 \mathrm{a}$ \\
$200 \mathrm{MPa}$ & $67.93 \pm 0.01 \mathrm{a}$ & $-1.91 \pm 0.01 \mathrm{a}$ & $31.92 \pm 0.01 \mathrm{~b}$ & $9.17 \pm 0.01 \mathrm{~b}$ & $58.03 \pm 0.02 \mathrm{~b}$ \\
$200 \mathrm{MPa}+$ vitamin C & $72.04 \pm 0.08 \mathrm{~b}$ & $0.63 \pm 0.02 \mathrm{~b}$ & $34.51 \pm 0.07 \mathrm{c}$ & $5.48 \pm 0.10 \mathrm{a}$ & $62.60 \pm 0.27 \mathrm{c}$ \\
7 days $/ 200 \mathrm{MPa}$ & $66.05 \pm 0.32 \mathrm{a}$ & $-1.35 \pm 0.05 \mathrm{~b}$ & $30.36 \pm 0.06 \mathrm{a}$ & $10.71 \pm 0.29 \mathrm{~b}$ & $56.93 \pm 0.27 \mathrm{~b}$ \\
7 days $/ 200 \mathrm{MPa}+$ vitamin C & $69.02 \pm 0.05 \mathrm{~b}$ & $-1.73 \pm 0.02 \mathrm{a}$ & $31.53 \pm 0.01 \mathrm{~b}$ & $8.10 \pm 0.04 \mathrm{a}$ & $56.06 \pm 0.06 \mathrm{a}$ \\
21 days/200 MPa & $67.69 \pm 0.33 \mathrm{a}$ & $4.72 \pm 0.03 \mathrm{~b}$ & $38.03 \pm 0.12 \mathrm{~b}$ & $11.20 \pm 0.18 \mathrm{~b}$ & $82.78 \pm 0.29 \mathrm{~b}$ \\
21 days/200 MPa + vitamin C & $68.17 \pm 0.01 \mathrm{a}$ & $-3.09 \pm 0.01 \mathrm{a}$ & $29.31 \pm 0.02 \mathrm{a}$ & $9.70 \pm 0.01 \mathrm{a}$ & $50.01 \pm 0.03 \mathrm{a}$ \\
\hline
\end{tabular}

Data are presented as the mean \pm S.D. from three independent experiments. Different letters in the same columns means statistically significant differences $(p>0.05)$

of vitamin $\mathrm{C}$, in juice was $128.57 \pm 2.16 \mathrm{mg} / \mathrm{L}$, which was about 10 times higher than the values reported by Á. SuárezJacobo et al. (2011). This fact could have been caused by a number of factors, such as variety, cultivation, but most probably by the fast oxidation of vitamin $\mathrm{C}$ during the processing of apple juice. Only $63.8 \%$ and $38.2 \%$ of DHAA was retained in apple juice treated at $100 \mathrm{MPa}$ and $200 \mathrm{MPa}$, respectively (Table 1). The L-dehydroascorbic acid (DHAA) as an oxidized form of L-ascorbic acid is considered to exhibit vitamin C activity, but it lacks antioxidant capacity (Á. Suárez-Jacobo et al., 2011).

Heat accelerates the oxidation of vitamin $\mathrm{C}$, but in this study, the product temperature did not exceed $35^{\circ} \mathrm{C}$. Despite this, vitamin $\mathrm{C}$ losses after HPH treatment were high. These results are consistent with Yu et al. (2014), who evaluated the influence of $\mathrm{HPH}$ treatment over vitamin $\mathrm{C}$ added to mulberry juices at a concentration of $400 \mathrm{mg} / \mathrm{L}$ during processing. They noted a decrease of AA by $58.7 \%$ in juices treated at $200 \mathrm{MPa}$. Tribst et al. (2011) showed an equally large decrease in vitamin $\mathrm{C}$ in mango nectar after HPH treatment. These authors suggested that some processing conditions, such as the presence of oxygen (lack of deaeration of juice before processing), high temperature, and shear in the homogenizing valve, contributed to vitamin $\mathrm{C}$ oxidation. Moreover, the presence of traces of $\mathrm{Be}-\mathrm{Cu}$ alloy, which comes from the erosion of the seals of the HPH equipment, may contribute to the oxidation of vitamin C. On the other hand, Á. Suárez-Jacobo et al. (2011) obtained only a $4.4 \%$ decrease in the total vitamin C content, and they did not note significant differences between the inlet temperatures $\left(4^{\circ} \mathrm{C}, 20^{\circ} \mathrm{C}\right)$ used.

No significant differences were found in the total vitamin $\mathrm{C}$ content in samples treated using several passes (Table 1). During 7 days of storage of the sample treated at $150 \mathrm{MPa}$, the degradation of DHAA was $34.1 \%$. Further storage resulted in greater losses in its content which after 28 days were as high as $91.2 \%$. This was probably caused by residual oxygen being dissolved in the juices.

\section{Total Phenolic Content and Polyphenol Profile}

The total phenolic content in fresh cloudy apple juice was $648.83 \pm 17.62 \mathrm{mg}$ GAE/L (Fig. 6). The TPC in apple juice reported by different authors ranges from 80 to $3540 \mathrm{mg} / \mathrm{L}$ (Schempp et al., 2016; Markowski et al., 2009). Such a large range of values results from the different varieties of apples, environmental conditions, and more importantly, the technology used in juice production, e.g. the use of mash enzymation. Cloudy juices contain a higher concentration of polyphenols than clear juices which has been confirmed in many studies (Markowski et al., 2015; Oszmianski et al., 2007). The dominant phenolic acid in apple juice is chlorogenic acid (Markowski et al., 2015; Oszmianski et al., 2007; Markowski et al., 2009), which was also confirmed in this study $(106.57 \pm 1.87 \mathrm{mg} / \mathrm{L})$. The predominant polyphenols detected in fresh apple juice were also phloridzin (27.08 \pm $0.19 \mathrm{mg} / \mathrm{L})$, gallic acid $(20.55 \pm 0.09 \mathrm{mg} / \mathrm{L})$, and then quercetin $(2.28 \pm 0.07 \mathrm{mg} / \mathrm{L})$ and ferulic acid $(1.28 \pm 0.01 \mathrm{mg} / \mathrm{L})$ (Table 4).

Figure 6 and Table 4 show that HPH treatment significantly influenced TPC and individual polyphenols in apple juices. The largest increase in content of these bioactive components, of almost $20 \%$, was recorded in samples treated at $150 \mathrm{MPa}$. A particularly large increase was recorded for quercetin and phloridzin-52\% and $47 \%$ respectively. This phenomenon may be related to the increased extractability of polyphenols from tissues or depolymerization from complexes as a result of high-pressure homogenization. An increase in the TPC of $11.5 \%$ was also observed by Karacam et al. (2015) in strawberry juice under HPH at 100 MPa. On the other hand, in this study, homogenization at $200 \mathrm{MPa}$ caused a small, 5\% decrease in the content of polyphenols. However, quercetin concentration decreased by almost $11 \%$. Velázquez-Estrada et al. (2013) reported that in orange juice, TPC was decreased maximally by $6.6 \%$ using pressure of up to $300 \mathrm{MPa}$. 
Table 4 Effect of HPH pressure level, number of $\mathrm{HPH}$ passes, and storage at $4{ }^{\circ} \mathrm{C}$ on the polyphenol profile (mg/L) of apple juice

\begin{tabular}{lllll}
\hline & Phloridzin & Chlorogenic acid & Ferulic acid & Gallic acid \\
\hline Influence of HPH pressure & & & & Quercetin \\
Fresh juice & $27.08 \pm 0.19 \mathrm{~b}$ & $106.57 \pm 1.87 \mathrm{~b}$ & $1.28 \pm 0.01 \mathrm{ab}$ & $20.55 \pm 0.09 \mathrm{a}$ \\
$100 \mathrm{MPa}$ & $28.57 \pm 0.07 \mathrm{c}$ & $109.92 \pm 0.59 \mathrm{~b}$ & $1.46 \pm 0.0 \mathrm{bc}$ & $20.65 \pm 0.05 \mathrm{a}$ \\
$150 \mathrm{MPa}$ & $39.81 \pm 0.01 \mathrm{~d}$ & $117.31 \pm 0.64 \mathrm{c}$ & $1.65 \pm 0.01 \mathrm{c}$ & $26.02 \pm 0.75 \mathrm{~b}$ \\
$200 \mathrm{MPa}$ & $25.67 \pm 0.06 \mathrm{a}$ & $100.74 \pm 0.60 \mathrm{a}$ & $1.24 \pm 0.02 \mathrm{a}$ & $19.76 \pm 0.05 \mathrm{a}$ \\
Influence of passes & & & & $2.87 \pm 0.07 \mathrm{~b}$ \\
$150 \mathrm{MPa} / 1$ pass & $39.81 \pm 0.01 \mathrm{e}$ & $117.31 \pm 0.64 \mathrm{~b}$ & $1.65 \pm 0.01 \mathrm{bc}$ & $26.02 \pm 0.75 \mathrm{~b}$ \\
$150 \mathrm{MPa} / 2$ passes & $37.93 \pm 0.01 \mathrm{~d}$ & $116.93 \pm 0.64 \mathrm{~b}$ & $1.67 \pm 0.01 \mathrm{c}$ & $25.93 \pm 0.08 \mathrm{~b}$ \\
$150 \mathrm{MPa} / 3$ passes & $35.28 \pm 0.65 \mathrm{c}$ & $114.77 \pm 0.26 \mathrm{ab}$ & $1.61 \pm 0.02 \mathrm{~b}$ & $24.40 \pm 0.48 \mathrm{ab}$ \\
$150 \mathrm{MPa} / 4$ passes & $33.40 \pm 0.65 \mathrm{~b}$ & $112.60 \pm 1.19 \mathrm{a}$ & $1.55 \pm 0.01 \mathrm{a}$ & $23.84 \pm 0.05 \mathrm{a}$ \\
$150 \mathrm{MPa} / 5$ passes & $31.32 \pm 0.38 \mathrm{a}$ & $112.22 \pm 0.95 \mathrm{a}$ & $1.51 \pm 0.01 \mathrm{a}$ & $22.80 \pm 0.08 \mathrm{a}$ \\
Influence of storage time & & & & $3.47 \pm 0.02 \mathrm{c}$ \\
$150 \mathrm{MPa} / 0$ day & $39.81 \pm 0.01 \mathrm{~d}$ & $117.31 \pm 0.64 \mathrm{~d}$ & $1.65 \pm 0.01 \mathrm{~d}$ & $2.95 \pm 0.07 \mathrm{ab}$ \\
$150 \mathrm{MPa} / 7$ days & $37.93 \pm 0.01 \mathrm{~d}$ & $116.49 \pm 0.14 \mathrm{~d}$ & $1.61 \pm 0.04 \mathrm{~d}$ & $2.85 \pm 0.02 \mathrm{a}$ \\
$150 \mathrm{MPa} / 14$ days & $29.28 \pm 0.75 \mathrm{c}$ & $103.16 \pm 0.48 \mathrm{c}$ & $1.37 \pm 0.01 \mathrm{c}$ & $24.55 \pm 0.15 \mathrm{c}$ \\
$150 \mathrm{MPa} / 21$ days & $21.73 \pm 0.75 \mathrm{~b}$ & $92.68 \pm 1.68 \mathrm{~b}$ & $1.27 \pm 0.02 \mathrm{~b}$ & $17.89 \pm 0.61 \mathrm{~b}$ \\
$150 \mathrm{MPa} / 28$ days & $17.58 \pm 0.21 \mathrm{a}$ & $80.41 \pm 0.35 \mathrm{a}$ & $1.13 \pm 0.03 \mathrm{a}$ & $16.01 \pm 0.19 \mathrm{a}$
\end{tabular}

Data are presented as the mean \pm S.D. from three independent experiments. Different letters in the same columns means statistically significant differences $(p>0.05)$

As the number of passes increased, the polyphenol content decreased by a maximum of $8 \%$ (Fig. 6). The less stable polyphenols under 5 passes of HPH were phloridzin (21\% degradation) and quercetin (17\% degradation). The high degradation of these compounds may be connected with the high rise in local temperature, despite the cooling system applied and their higher sensitivity to temperature. Karacam et al. (2015) treated strawberry juice with HPH and observed that the use of 5 passes did not cause a significant difference in the polyphenol content.
Seven days of storage did not affect the TPC; the polyphenol content only began to decrease after the 14th day, and on the 28th day it was $471.00 \pm 15.79 \mathrm{mg} \mathrm{GAE} / \mathrm{L}$, therefore $39 \%$ lower. Guan et al. (2016) also found a similar tendency in the TPC of mango juice after HPH treatment. They noticed that 18 days of storage did not cause significant differences in the polyphenol content and after 30 days of storage, the juice contained $28.6 \%$ less polyphenol compounds than in the sample immediately after the application of HPH. Polyphenols vary in their susceptibility to oxidation. Sanoner et al. (1999)
Fig. 6 Effect of pressure level, number of $\mathrm{HPH}$ passes at 150 $\mathrm{MPa}$, and storage at $4{ }^{\circ} \mathrm{C}$ of $\mathrm{HPH}$ on the total content of polyphenols and antioxidant capacity of apple juice

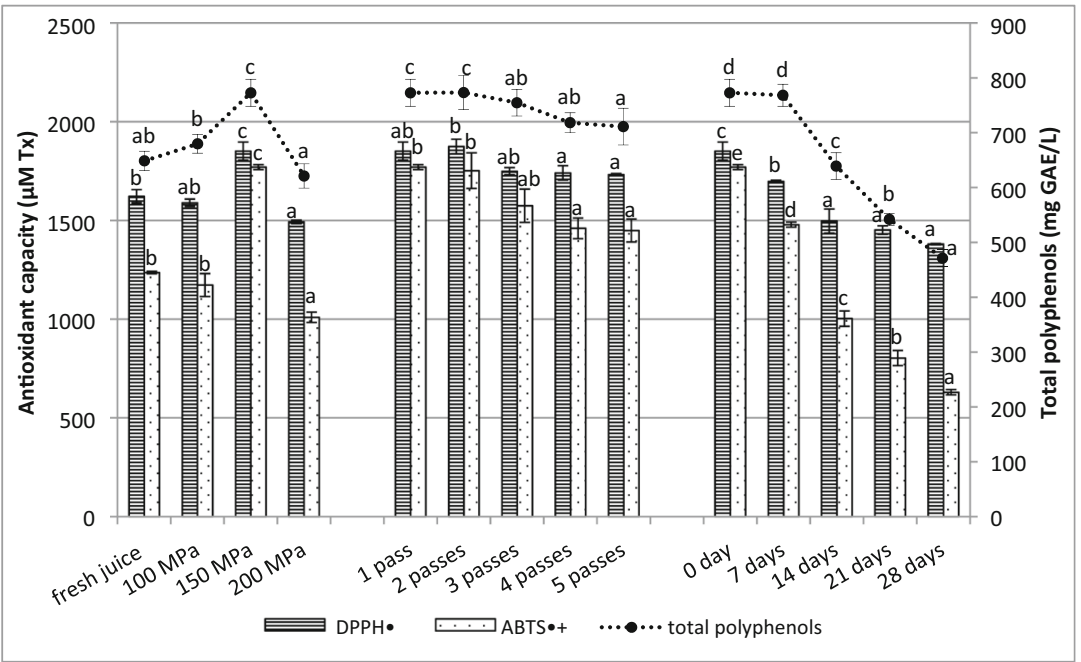


found that oxidation resulted in a significant decrease in apple polyphenols, particularly procyanidins and catechins, whereas hydroxycinnamic acids were mostly preserved. Similar results were obtained in this study; during 28 days of storage, both the chlorogenic and ferulic acid content decreased by $31.5 \%$, while phloridzin and quercetin degraded faster with a loss of $56 \%$ and $48 \%$ respectively. This phenomenon may be explained by the varying affinity of PPO to different polyphenols (Yu et al., 2018).

\section{Antioxidant Capacity (DPPH', $\mathrm{ABTS}^{\circ+}$ )}

The antioxidant capacity of apple juice was evaluated using $\mathrm{DPPH}^{\bullet}$ and $\mathrm{ABTS}^{\bullet+}$ assays (Fig. 6). The antioxidant potential of fresh apple juice measured with DPPH $^{\bullet}$ and ABTS $^{\bullet+}$ tests was $1622.2 \pm 33.6$ and $1236.7 \pm 6.6 \mu \mathrm{M}$ Trolox equivalent, respectively. The antioxidant potential in apple juices after $\mathrm{HPH}$ treatment decreased, except for $150 \mathrm{MPa}$. In this case, measurements using the $\mathrm{DPPH}^{\circ}$ and $\mathrm{ABTS}^{\circ+}$ methods showed an increase of $14.1 \%$ and $43.2 \%$, respectively. Using multiple passes resulted in a decrease in the antioxidant capacity as in the case of the total polyphenolic content. The values of the tested antioxidant capacities measured using both tests were positively correlated with TPC and individual polyphenols, as evidenced by the high linear correlation coefficients, significant at a $99 \%$ confidence level (Table 5), which indicates strong dependence between the antioxidant potential and phenolic content. A positive correlation was also observed between $\mathrm{DPPH}^{\circ}$ and $\mathrm{ABTS}^{\circ+}(r=0.983)$. These results are in accordance with Á. Suárez-Jacobo et al. (2011), who evaluated the influence of the HPH treatment of apple juices and observed the relationship between the results of the antioxidant assay with single polyphenols and the total polyphenolic content. Furthermore, they found an inverse correlation between the antioxidant potential and the total vitamin $\mathrm{C}$ content. In this study, there was low but significant $(p \leq 0.01)$ correlation between vitamin $\mathrm{C}$ and antioxidant capacity (Table 5).

Storage has a significant effect on the antiradical activity determined with both $\mathrm{DPPH}^{\bullet}$ and $\mathrm{ABTS}^{\bullet+}$ tests (Fig. 6). Results are in accordance with another study conducted by

Table 5 Pearson correlation $(r)$ between individual polyphenols, total polyphenol content (TPC), vitamin C, and antioxidant activity $\left(\mathrm{DPPH}^{*}, \mathrm{ABTS}^{*+}\right)$ for apple juice under $\mathrm{HPH}$

\begin{tabular}{lcc}
\hline & DPPH $^{\bullet}$ & ABTS $^{\bullet+}$ \\
\hline Phloridzin & 0.903 & 0.917 \\
Chlorogenic acid & 0.875 & 0.896 \\
Ferulic acid & 0.877 & 0.881 \\
Gallic acid & 0.958 & 0.961 \\
Quercetin & 0.858 & 0.868 \\
TPC & 0.916 & 0.931 \\
Vitamin C & 0.455 & 0.465 \\
\hline
\end{tabular}

Significant at $p \leq 0.01$
Guan et al. (2016), who demonstrated that the changes to the antioxidant capacities of mango juice corresponded to the degradation changes of bioactive compounds throughout the entire storage period (60 days) at room temperature.

\section{Conclusions}

Based on the results of this work, it can be concluded that $\mathrm{HPH}$ significantly affects rheological properties, such as the apparent viscosity, turbidity, and particle size distribution of apple juice. Changes in the apparent viscosity might be connected with particle size reduction and high $\mathrm{PG}$ activity. The maximum pressure used in this work $(200 \mathrm{MPa})$ resulted in a $1.4 \log$ reduction in microorganisms and a $20 \%$ decrease in the activity of oxidoreductive enzymes, while the PG activity did not change significantly. The application of $200 \mathrm{MPa}$ caused a decrease in the TPC and vitamin $\mathrm{C}$ of $4.3 \%$ and $61.8 \%$, respectively. Quercetin was the most sensitive to high pressure $(200 \mathrm{MPa})$, whereas the ferulic and gallic acids were the most stable of the individual polyphenols detected in apple juice. HPH treatment at $200 \mathrm{MPa}$ resulted in a total colour difference in apple juice visible to the inexperienced observer $(\Delta E=7.0)$. The use of different pressure levels resulted in higher and more significant changes in the quality parameters than after using multiple passes. The results indicate that $\mathrm{HPH}$-treated apple juice at $150 \mathrm{MPa}$ stored at $4^{\circ} \mathrm{C}$ has a 7 day shelf-life, maintaining colour, TPC, and antioxidant potential.

Acknowledgements The authors would like to thank Marzena Połaska (Prof. Wacław Dabrowski Institute of Agricultural and Food Biotechnology, Department of Microbiology, Poland) for performing microbiological analyses.

Author Contribution Justyna Szczepańska: conceptualization, methodology, validation, investigation, formal analysis, visualization, writingoriginal draft.

Sylwia Skapska: writing — review and editing, supervision.

Krystian Marszałek: conceptualization, writing - review and editing, supervision.

Funding This research was supported by project number 2019/33/N/ NZ9/02560 of the National Science Centre, Poland.

\section{Declarations}

Conflict of Interest The authors declare no competing interests.

Open Access This article is licensed under a Creative Commons Attribution 4.0 International License, which permits use, sharing, adaptation, distribution and reproduction in any medium or format, as long as you give appropriate credit to the original author(s) and the source, provide a link to the Creative Commons licence, and indicate if changes were made. The images or other third party material in this article are included in the article's Creative Commons licence, unless indicated otherwise in a 
credit line to the material. If material is not included in the article's Creative Commons licence and your intended use is not permitted by statutory regulation or exceeds the permitted use, you will need to obtain permission directly from the copyright holder. To view a copy of this licence, visit http://creativecommons.org/licenses/by/4.0/.

\section{References}

AIJN. (2015). Code of Practice for the Evaluation of fruit and vegetable juices. European Fruit Juice Association.

Augusto, P. E. D., Ibarz, A., \& Cristianini, M. (2012). Effect of high pressure homogenization (HPH) on the rheological properties of a fruit juice serum model. Journal of Food Engineering, 111(2), 474 477. https://doi.org/10.1016/j.jfoodeng.2012.02.033.

Augusto, P. E. D., Ibarz, A., \& Cristianini, M. (2013). Effect of high pressure homogenization (HPH) on the rheological properties of tomato juice: creep and recovery behaviours. Food Research International, 54(1), 169-176. https://doi.org/10.1016/j.foodres. 2013.06.027.

Augusto, P. E. D., Tribst, A. A. L., \& Cristianini, M. (2018). High hydrostatic pressure and high-pressure homogenization processing of fruit juices. fruit juices: extraction, composition, quality and analysis. https://doi.org/10.1016/B978-0-12-802230-6.00020-5

Bot, F., Calligaris, S., Cortella, G., Plazzotta, S., Nocera, F., \& Anese, M. (2018). Study on high pressure homogenization and high power ultrasound effectiveness in inhibiting polyphenoloxidase activity in apple juice. Journal of Food Engineering, 221, 70-76. https://doi. org/10.1016/j.jfoodeng.2017.10.009.

Briñez, W. J., Roig-Sagués, A. X., Herrero, M. M. H., \& López, B. G. (2007). Inactivation of Staphylococcus spp. strains in whole milk and orange juice using ultra high pressure homogenisation at inlet temperatures of 6 and $20^{\circ} \mathrm{C}$. Food Control, 18(10), 1282-1288. https://doi.org/10.1016/j.foodcont.2006.09.002.

Calligaris, S., Foschia, M., Bartolomeoli, I., Maifreni, M., \& Manzocco, L. (2012). Study on the applicability of high-pressure homogenization for the production of banana juices. LWT - Food Science and Technology, 45(1), 117-121. https://doi.org/10.1016/j.lwt.2011.07. 026.

Carbonell, J. V., Navarro, J. L., Izquierdo, L., \& Sentandreu, E. (2013). Influence of high pressure homogenization and pulp reduction on residual pectinmethylesterase activity, cloud stability and acceptability of Lane Late orange juice: A study to obtain high quality orange juice with extended shelf life. Journal of Food Engineering, 119(3), 696-700. https://doi.org/10.1016/j.jfoodeng. 2013.06.041.

Carreño, J. M., Gurrea, M. C., Sampedro, F., \& Carbonell, J. V. (2011). Effect of high hydrostatic pressure and high-pressure homogenisation on Lactobacillus plantarum inactivation kinetics and quality parameters of mandarin juice. European Food Research and Technology, 232(2), 265-274. https://doi.org/10.1007/s00217-0101381-9.

Cerdán-Calero, M., Izquierdo, L., \& Sentandreu, E. (2013). Valencia Late orange juice preserved by pulp reduction and high pressure homogenization: sensory quality and gas chromatography-mass spectrometry analysis of volatiles. LWT - Food Science and Technology, 51(2), 476-483. https://doi.org/10.1016/j.lwt.2012.11.016.

Codina-Torrella, I., Guamis, B., Ferragut, V., \& Trujillo, A. J. (2017). Potential application of ultra-high pressure homogenization in the physico-chemical stabilization of tiger nuts' milk beverage. Innovative Food Science and Emerging Technologies, 40, 42-51. https://doi.org/10.1016/j.ifset.2016.06.023.
Cserhalmi, Z., Sass-Kiss, A., Tóth-Markus, M., \& Lechner, N. (2006). Study of pulsed electric field treated citrus juices. Innovative Food Science and Emerging Technologies, 7(1-2), 49-54. https://doi.org/ 10.1016/j.ifset.2005.07.001.

Dachmann, E., Hengst, C., Ozcelik, M., Kulozik, U., \& Dombrowski, J. (2018). Impact of hydrocolloids and homogenization treatment on the foaming properties of raspberry fruit Puree. Food and Bioprocess Technology, 11(12), 2253-2264. https://doi.org/10. 1007/s11947-018-2179-1.

Donsì, F., Esposito, L., Lenza, E., Senatore, B., \& Ferrari, G. (2009). Production of shelf-stable annurca apple juice with pulp by high pressure homogenization. International Journal of Food Engineering, 5(4). https://doi.org/10.2202/1556-3758.1602

Eisenmenger, M. J., \& Reyes-De-Corcuera, J. I. (2009). High pressure enhancement of enzymes: a review. Enzyme and Microbial Technology, 45(5), 331-347. https://doi.org/10.1016/j.enzmictec. 2009.08.001.

EN 12630. (1999). Fruit and vegetable juices. Determination of glucose, fructose, sorbitol and sucrose contents. Method using highperformance liquid chromatography

Floury, J., Bellettre, J., Legrand, J., \& Desrumaux, A. (2004). Analysis of a new type of high pressure homogeniser. A study of the flow pattern. Chemical Engineering Science, 59(4), 843-853. https://doi. org/10.1016/j.ces.2003.11.017.

Galvão, K. C. S., Vicente, A. A., \& Sobral, P. J. A. (2017). Development, characterization, and stability of o/w pepper Nnnoemulsions produced by high-pressure homogenization. Food and Bioprocess Technology, 11(2), 355-367. https://doi.org/10.1007/s11947-0172016-y.

Gao, X., Ohlander, M., Jeppsson, N., Björk, L., \& Trajkovski, V. (2000). Changes in antioxidant effects and their relationship to phytonutrients in fruits of sea buckthorn (Hippophae rhamnoides L.) during maturation. Journal of Agricultural and Food Chemistry, 48(5), 1485-1490. https://doi.org/10.1021/jf991072g.

Guan, Y., Zhou, L., Bi, J., Yi, J., Liu, X., Chen, Q., Wu, X., \& Zhou, M. (2016). Change of microbial and quality attributes of mango juice treated by high pressure homogenization combined with moderate inlet temperatures during storage. Innovative Food Science and Emerging Technologies, 36, 320-329. https://doi.org/10.1016/j. ifset.2016.07.009.

Hagerman, A. E., \& Austin, P. J. (1986). Continuous spectrophotometric assay for plant pectin methyl esterase. Journal of Agricultural and Food Chemistry, 34(3), 440-444. https://doi.org/10.1021/ jf00069a015.

Karacam, C. H., Sahin, S., \& Oztop, M. H. (2015). Effect of high pressure homogenization (microfluidization) on the quality of Ottoman Strawberry (F. Ananassa) juice. LWT - Food Science and Technology, 64(2), 932-937. https://doi.org/10.1016/j.lwt.2015.06. 064.

Kubo, M. T. K., Augusto, P. E. D., \& Cristianini, M. (2013). Effect of high pressure homogenization $(\mathrm{HPH})$ on the physical stability of tomato juice. Food Research International, 51(1), 170-179. https://doi.org/10.1016/j.foodres.2012.12.004.

Lacroix, N., Fliss, I., \& Makhlouf, J. (2005). Inactivation of pectin methylesterase and stabilization of opalescence in orange juice by dynamic high pressure. Food Research International, 38(5), 569576. https://doi.org/10.1016/j.foodres.2004.11.010.

Leite, T. S., Augusto, P. E. D., \& Cristianini, M. (2014). The use of high pressure homogenization (HPH) to reduce consistency of concentrated orange juice (COJ). Innovative Food Science and Emerging Technologies, 26, 124-133. https://doi.org/10.1016/j.ifset.2014.08. 005.

Leite, T. S., Augusto, P. E. D., \& Cristianini, M. (2016). Frozen concentrated orange juice (FCOJ) processed by the high pressure homogenization (HPH) technology: effect on the ready-to-drink juice. 
Food and Bioprocess Technology, 9(6), 1070-1078. https://doi.org/ 10.1007/s11947-016-1688-z.

Maresca, P., Donsì, F., \& Ferrari, G. (2011). Application of a multi-pass high-pressure homogenization treatment for the pasteurization of fruit juices. Journal of Food Engineering, 104(3), 364-372. https://doi.org/10.1016/j.jfoodeng.2010.12.030.

Markowski, J., Baron, A., Mieszczakowska, M., \& Płocharski, W. (2009). Chemical composition of French and Polish cloudy apple juices. The Journal of Horticultural Science and Biotechnology, 84(6), 68-74. https://doi.org/10.1080/14620316.2009.11512598.

Markowski, J., Baron, A., Le Quéré, J.-M., \& Płocharski, W. (2015). Composition of clear and cloudy juices from French and Polish apples in relation to processing technology. LWT - Food Science and Technology, 62(1), 813-820. https://doi.org/10.1016/j.lwt. 2014.11.048.

Martínez-Hernández, G. B., Álvarez-Hernández, M. H., \& ArtésHernández, F. (2019). Browning control using cyclodextrins in high pressure-treated apple juice. Food and Bioprocess Technology., 12(4), 694-703. https://doi.org/10.1007/s11947-019-2242-6.

Maskan, M. (2001). Kinetics of colour change of kiwifruits during hot air and microwave drying. Journal of Food Engineering, 48(2), 169175. https://doi.org/10.1016/S0260-8774(00)00154-0.

McKay, A. M., Linton, M., Stirling, J., Mackle, A., \& Patterson, M. F. (2011). A comparative study of changes in the microbiota of apple juice treated by high hydrostatic pressure (HHP) or high pressure homogenisation (HPH). Food Microbiology, 28(8), 1426-1431. https://doi.org/10.1016/j.fm.2011.06.013.

Navarro, J. L., Izquierdo, L., Carbonell, J. V., \& Sentandreu, E. (2014). Effect of $\mathrm{pH}$, temperature and maturity on pectinmethylesterase inactivation of citrus juices treated by high-pressure homogenization. LWT - Food Science and Technology, 57(2), 785-788. https://doi. org/10.1016/j.lwt.2014.01.033.

Odriozola-Serrano, I., Hernández-Jover, T., \& Martín-Belloso, O. (2007). Comparative evaluation of UV-HPLC methods and reducing agents to determine vitamin C in fruits. Food Chemistry, 105(3), 11511158. https://doi.org/10.1016/j.foodchem.2007.02.037.

Oszmianski, J., Wolniak, M., Wojdylo, A., \& Wawer, I. (2007). Comparative study of polyphenolic content and antiradical activity of cloudy and clear apple juices. Journal of the Science of Food and Agriculture, 87(4), 573-579. https://doi.org/10.1002/jsfa.2707.

Pan, S.-Y., Chen, C.-H., \& Lai, L.-S. (2012). Effect of tapioca starch/ decolorized hsian-tsao leaf gum-based active coatings on the qualities of fresh-cut apples. Food and Bioprocess Technology, 6(8), 2059-2069. https://doi.org/10.1007/s11947-012-0907-5.

Pathanibul, P., Taylor, T. M., Davidson, P. M., \& Harte, F. (2009). Inactivation of Escherichia coli and Listeria innocua in apple and carrot juices using high pressure homogenization and nisin. International Journal of Food Microbiology, 129(3), 316-320. https://doi.org/10.1016/j.ijfoodmicro.2008.12.020.

Patrignani, F., Vannini, L., Kamdem, S. L. S., Lanciotti, R., \& Guerzoni, M. E. (2010). Potentialities of high-pressure homogenization to inactivate Zygosaccharomyces bailii in fruit juices. Journal of Food Science, 75(2), M116-M120. https://doi.org/10.1111/j.1750-3841. 2009.01508.x.

Patrignani, F., Tabanelli, G., Siroli, L., Gardini, F., \& Lanciotti, R. (2013). Combined effects of high pressure homogenization treatment and citral on microbiological quality of apricot juice. International Journal of Food Microbiology, 160(3), 273-281. https://doi.org/10.1016/j.ijfoodmicro.2012.10.021.

Pereda, J., Ferragut, V., Quevedo, J. M., Guamis, B., \& Trujillo, A. J. (2007). Effects of ultra-high pressure homogenization on microbial and physicochemical shelf life of milk. Journal of Dairy Science, 90(3), 1081-1093. https://doi.org/10.3168/jds.S0022-0302(07) 71595-3.

Pires, T. D. C. R., \& Finardi-Filho, F. (2005). Extraction and assay of pectic enzymes from Peruvian carrot (Arracacia xanthorriza
Bancroft.). Food Chemistry, 89(1), 85-92. https://doi.org/10.1016/ j.foodchem.2004.02.023.

PN-EN ISO 4833-1. (2013). Microbiology of the food chain - horizontal method for the enumeration of microorganisms - Part 1: Colony count at $30^{\circ} \mathrm{C}$ by the pour plate technique

PN-ISO 21527-1. (2009). Microbiology of food and animal feeding stuffs - horizontal method for the enumeration of yeast and moulds - Part 1: colony count technique in products with water activity greater than 0,95

Poliseli-Scopel, F. H., Hernández-Herrero, M., Guamis, B., \& Ferragut, V. (2012). Comparison of ultra high pressure homogenization and conventional thermal treatments on the microbiological, physical and chemical quality of soymilk. LWT - Food Science and Technology, 46(1), 42-48. https://doi.org/10.1016/j.lwt.2011.11. 004.

Rao, M. A., Rizvi, S. S. H., Datta, A. K., \& Ahmed, J. (2014). Engineering properties of foods, fourth edition. Engineering Properties of Foods, Fourth Edition. https://doi.org/10.1201/ b16897.

Re, R., Pellegrini, N., Proteggente, A., Pannala, A., Yang, M., \& RiceEvans, C. (1999). Antioxidant activity applying an improved ABTS radical cation decolorization assay. Free Radical Biology and Medicine, 26(9-10), 1231-1237. https://doi.org/10.1016/S08915849(98)00315-3.

Riahi, E., \& Ramaswamy, H. S. (2003). High-pressure processing of apple juice: kinetics of pectin methyl esterase inactivation. Biotechnology Progress, 19(3), 908-914. https://doi.org/10.1021/ bp025667z.

Saldo, J., Suárez-Jacobo, Á., Gervilla, R., Guamis, B., \& Roig-Sagués, A. X. (2009). Use of ultra-high-pressure homogenization to preserve apple juice without heat damage. High Pressure Research, 29(1), 52-56. https://doi.org/10.1080/08957950802715112.

Sanoner, P., Guyot, S., Marnet, N., Molle, D., \& Drilleau, J.-F. (1999). Polyphenol profiles of French cider apple varieties (Malus domestica sp.). Journal of Agricultural and Food Chemistry, 47(12), 4847-4853. https://doi.org/10.1021/jf990563y.

Schempp, H., Christof, S., Mayr, U., \& Treutter, D. (2016). Phenolic compounds in juices of apple cultivars and their relation to antioxidant activity. Journal of Applied Botany and Food Quality, 89, 1120. https://doi.org/10.5073/JABFQ.2016.089.002.

Steffe, J. F., Mohamed, I. O., \& Ford, E. W. (1983). Rheological properties of fluid foods. In Paper - American Society of Agricultural Engineers. Retrieved from https://www.scopus.com/inward/record. uri?eid=2-s2.0-0020936174\&partnerID $=40 \& \mathrm{md} 5=$ $692037 \mathrm{c} 845 \mathrm{a} 85 \mathrm{fdb} 0375 \mathrm{f5} 90 \mathrm{c} 9 \mathrm{c} 3 \mathrm{e} 5 \mathrm{a} 8$

Suárez-Jacobo, Á., Gervilla, R., Guamis, B., Roig-Sagués, A. X., \& Saldo, J. (2010). Effect of UHPH on indigenous microbiota of apple juice. A preliminary study of microbial shelf-life. International Journal of Food Microbiology, 136(3), 261-267. https://doi.org/ 10.1016/j.ijfoodmicro.2009.11.011

Suárez-Jacobo, Á., Rüfer, C. E., Gervilla, R., Guamis, B., Roig-Sagués, A. X., \& Saldo, J. (2011). Influence of ultra-high pressure homogenisation on antioxidant capacity, polyphenol and vitamin content of clear apple juice. Food Chemistry, 127(2), 447-454. https://doi.org/ 10.1016/j.foodchem.2010.12.152.

Suárez-Jacobo, A., Saldo, J., Rüfer, C. E., Guamis, B., Roig-Sagués, A. X., \& Gervilla, R. (2012). Aseptically packaged UHPH-Treated apple juice: safety and quality parameters during storage. Journal of Food Engineering, 109(2), 291-300. https://doi.org/10.1016/j. jfoodeng.2011.09.007.

Tan, J., \& Kerr, W. L. (2015). Rheological properties and microstructure of tomato puree subject to continuous high pressure homogenization. Journal of Food Engineering, 166, 45-54. https://doi.org/10. 1016/j.jfoodeng.2015.05.025.

Terefe, N. S., \& Buckow, R. (2017). High-pressure processing effects on endogenous enzymes in fruits and vegetables. High Pressure 
Processing of Fruit and Vegetable Products. https://doi.org/10. 1201/9781315121123.

Terefe, N. S., Yang, Y. H., Knoerzer, K., Buckow, R., \& Versteeg, C. (2010). High pressure and thermal inactivation kinetics of polyphenol oxidase and peroxidase in strawberry puree. Innovative Food Science and Emerging Technologies, 11(1), 52-60. https://doi.org/ 10.1016/j.ifset.2009.08.009.

Tribst, A. A. L., Franchi, M. A., de Massaguer, P. R., \& Cristianini, M. (2011). Quality of mango nectar processed by high-pressure homogenization with optimized heat treatment. Journal of Food Science, 76(2), M106-M110. https://doi.org/10.1111/j.1750-3841.2010. 02006.x.

Tsao, R., Yang, R., Young, J. C., \& Zhu, H. (2003). Polyphenolic profiles in eight apple cultivars using high-performance liquid chromatography (HPLC). Journal of Agricultural and Food Chemistry, 51(21), 6347-6353. https://doi.org/10.1021/jf0346298.

Tsao, R., Yang, R., Xie, S., Sockovie, E., \& Khanizadeh, S. (2005). Which polyphenolic compounds contribute to the total antioxidant activities of apple? Journal of Agricultural and Food Chemistry, 53(12), 4989-4995. https://doi.org/10.1021/jf048289h.

Vachon, J. F., Kheadr, E. E., Giasson, J., Paquin, P., \& Fliss, I. (2002). Inactivation of foodborne pathogens in milk using dynamic high pressure. Journal of Food Protection, 65(2), 345-352. https://doi. org/10.4315/0362-028X-65.2.345.

Velázquez-Estrada, R. M., Hernández-Herrero, M. M., Guamis-López, B., \& Roig-Sagués, A. X. (2012). Impact of ultra high pressure homogenization on pectin methylesterase activity and microbial characteristics of orange juice: a comparative study against conventional heat pasteurization. Innovative Food Science and Emerging Technologies, 13(JANUARY), 100-106. https://doi.org/10.1016/j. ifset.2011.09.001.

Velázquez-Estrada, R. M., Hernández-Herrero, M. M., Rüfer, C. E., Guamis-López, B., \& Roig-Sagués, A. X. (2013). Influence of ultra high pressure homogenization processing on bioactive compounds and antioxidant activity of orange juice. Innovative Food Science and Emerging Technologies, 18, 89-94. https://doi.org/10.1016/j. ifset.2013.02.005.

Welti-Chanes, J., Ochoa-Velasco, C. E., \& Guerrero-Beltrán, J. Á. (2009). High-pressure homogenization of orange juice to inactivate pectinmethylesterase. Innovative Food Science and Emerging Technologies, 10(4), 457-462. https://doi.org/10.1016/j.ifset.2009. 05.012 .

Włodarska, K., Pawlak-Lemańska, K., Górecki, T., \& Sikorska, E. (2016). Perception of apple juice: a comparison of physicochemical measurements, descriptive analysis and consumer responses. Journal of Food Quality, 39(4), 351-361. https://doi.org/10.1111/ jfq. 12208 .

Wojdyło, A., Oszmiański, J., \& Laskowski, P. (2008). Polyphenolic compounds and antioxidant activity of new and old apple varieties. Journal of Agricultural and Food Chemistry, 56(15), 6520-6530. https://doi.org/10.1021/jf800510j.

Xu, J., Zhou, L., Miao, J., Yu, W., Zou, L., Zhou, W., Liu, C., \& Liu, W. (2020). Effect of cinnamon essential oil nanoemulsion combined with ascorbic acid on enzymatic browning of cloudy apple juice. Food and Bioprocess Technology., 13(5), 860-870. https://doi.org/ 10.1007/s11947-020-02443-8.

Yen, G.-C., \& Chen, H.-Y. (1995). Antioxidant activity of various tea extracts in relation to their antimutagenicity. Journal of Agricultural and Food Chemistry, 43(1), 27-32. https://doi.org/10.1021/ jf00049a007.

Yu, Y., Xu, Y., Wu, J., Xiao, G., Fu, M., \& Zhang, Y. (2014). Effect of ultra-high pressure homogenisation processing on phenolic compounds, antioxidant capacity and anti-glucosidase of mulberry juice. Food Chemistry, 153, 114-120. https://doi.org/10.1016/j.foodchem. 2013.12.038.

Yu, Y., Jin, T. Z., Fan, X., \& Wu, J. (2018). Biochemical degradation and physical migration of polyphenolic compounds in osmotic dehydrated blueberries with pulsed electric field and thermal pretreatments. Food Chemistry, 239, 1219-1225. https://doi.org/10. 1016/j.foodchem.2017.07.071.

Zhou, L., Guan, Y., Bi, J., Liu, X., Yi, J., Chen, Q., Wu, X., \& Zhou, M. (2017). Change of the rheological properties of mango juice by high pressure homogenization. LWT, 82, 121-130. https://doi.org/10. 1016/j.lwt.2017.04.038.

Publisher's Note Springer Nature remains neutral with regard to jurisdictional claims in published maps and institutional affiliations. 